\title{
Article \\ Citrate-Coated Superparamagnetic Iron Oxide Nanoparticles Enable a Stable Non-Spilling Loading of T Cells and Their Magnetic Accumulation
}

\author{
Philipp Boosz ${ }^{1,2,+}$, Felix Pfister ${ }^{1,+}$, Rene Stein ${ }^{1}$, Bernhard Friedrich ${ }^{1} \mathbb{D}$, Lars Fester ${ }^{3}$, Julia Band ${ }^{1}$, \\ Marina Mühlberger ${ }^{1}$, Eveline Schreiber ${ }^{1}$, Stefan Lyer ${ }^{1}{ }^{\mathbb{D}}$, Diana Dudziak ${ }^{4,5,6,7}$, Christoph Alexiou ${ }^{1,+}$ \\ and Christina Janko $1, *,+(\mathbb{D}$
}

Citation: Boosz, P.; Pfister, F.; Stein, R.; Friedrich, B.; Fester, L.; Band, J.; Mühlberger, M.; Schreiber, E.; Lyer, S.; Dudziak, D.; et al. Citrate-Coated Superparamagnetic Iron Oxide Nanoparticles Enable a Stable Non-Spilling Loading of T Cells and Their Magnetic Accumulation. Cancers 2021, 13, 4143. https:// doi.org/10.3390/cancers13164143

Academic Editors: Moriaki Kusakabe and Akihiro Kuwahata

Received: 14 June 2021

Accepted: 13 August 2021

Published: 17 August 2021

Publisher's Note: MDPI stays neutral with regard to jurisdictional claims in published maps and institutional affiliations.

Copyright: (c) 2021 by the authors. Licensee MDPI, Basel, Switzerland. This article is an open access article distributed under the terms and conditions of the Creative Commons Attribution (CC BY) license (https:// creativecommons.org/licenses/by/ $4.0 /)$.
1 Department of Otorhinolaryngology, Head and Neck Surgery, Section of Experimental Oncology and Nanomedicine (SEON), Else Kröner-Fresenius-Stiftung Professorship, Universitätsklinikum Erlangen, 91054 Erlangen, Germany; philipp.boosz@fau.de (P.B.); felix.pfister@uk-erlangen.de (F.P.); rene.stein@uk-erlangen.de (R.S.); bernhard.friedrich@uk-erlangen.de (B.F.); julia.band@uk-erlangen.de (J.B.); marina.muehlberger@uk-erlangen.de (M.M.); eveline.schreiber@uk-erlangen.de (E.S.); stefan.lyer@uk-erlangen.de (S.L.); christoph.alexiou@uk-erlangen.de (C.A.)

2 Friedrich-Alexander-Universität Erlangen-Nürnberg (FAU), 91054 Erlangen, Germany

3 Institute of Anatomy and Cell Biology, Friedrich-Alexander-Universität Erlangen-Nürnberg (FAU), 91054 Erlangen, Germany; lars.fester@uk-erlangen.de

4 Laboratory of Dendritic Cell Biology, Department of Dermatology, Universitätsklinikum Erlangen, 91054 Erlangen, Germany; diana.dudziak@uk-erlangen.de

5 Deutsches Zentrum Immuntherapie (DZI), 91054 Erlangen, Germany

6 Comprehensive Cancer Center Erlangen-EMN (CCC ER-EMN), 91054 Erlangen, Germany

Medical Immunology Campus Erlangen, 91054 Erlangen, Germany

* Correspondence: christina.janko@uk-erlangen.de

$+\quad$ These authors contributed equally to this paper.

Simple Summary: In cancer patients, adoptive $\mathrm{T}$ cell transfer shall increase the number of circulating cytotoxic $\mathrm{T}$ cells to foster anti-tumor immune responses. In solid tumors, however, lack of lymphocyte infiltration into the tumor impairs treatment efficacy due to the immune-suppressive tumor microenvironment. To make cells controllable by external forces, we loaded primary human $\mathrm{T}$ cells with citrate-coated superparamagnetic iron oxide nanoparticles (SPIONs). SPIONs were tightly attached to the plasma membrane and also taken up intracellularly into vesicles. With their nanoparticle cargo, we were able to magnetically accumulate them, which is a promising finding for future magnetic delivery of immune cells after adoptive transfer.

Abstract: T cell infiltration into a tumor is associated with a good clinical prognosis of the patient and adoptive $\mathrm{T}$ cell therapy can increase anti-tumor immune responses. However, immune cells are often excluded from tumor infiltration and can lack activation due to the immune-suppressive tumor microenvironment. To make $\mathrm{T}$ cells controllable by external forces, we loaded primary human CD3+ T cells with citrate-coated superparamagnetic iron oxide nanoparticles (SPIONs). Since the efficacy of magnetic targeting depends on the amount of SPION loading, we investigated how experimental conditions influence nanoparticle uptake and viability of cells. We found that loading in the presence of serum improved both the colloidal stability of SPIONs and viability of T cells, whereas stimulation with CD3/CD28/CD2 and IL-2 did not influence nanoparticle uptake. Furthermore, SPION loading did not impair cytokine secretion after polyclonal stimulation. We finally achieved $1.4 \mathrm{pg}$ iron loading per cell, which was both located intracellularly in vesicles and bound to the plasma membrane. Importantly, nanoparticles did not spill over to non-loaded cells. Since SPION-loading enabled efficient magnetic accumulation of $\mathrm{T}$ cells in vitro under dynamic conditions, we conclude that this might be a good starting point for the investigation of in vivo delivery of immune cells. 
Keywords: nanomedicine; superparamagnetic iron oxide nanoparticles (SPIONs); adoptive T cell transfer; immune therapy; targeted transport; solid tumor; magnetic targeting

\section{Introduction}

Cancer is the second leading cause of mortality worldwide with over 8.7 million deaths in 2016 and is expected to become the leading one by 2060 [1]. Despite death rates have been steadily declining in the last years, treatment is still complex. Surgery, chemotherapy, radiotherapy, alone or in combination, have represented the main treatment options for a long time. Since the immune system itself can recognize and eliminate tumor cells, immune therapy has evolved. Infiltration of solid tumors with immune cells has turned out to be an important criterion for therapy as well as for patient prognosis [2,3]. Especially CD8+ $\mathrm{T}$ cells among the tumor-infiltrating lymphocytes (TILs) have a favorable impact on disease burden and progression [4,5]. Adoptive transfer of immune effector cells shall increase the amount of tumor-infiltrating lymphocytes to boost the anti-tumor immune response. This procedure utilizes the isolation of peripheral $\mathrm{T}$ cells or TILs from a patient and the expansion and modification to increase the immunogenic anti-tumor activity [6]. However, it has been shown that after the transfer of the $\mathrm{T}$ cells only a small number infiltrated into the tumor, resulting in only minor anti-tumor effects $[7,8]$. Irregular tumor vasculature, barrier function of the tumor epithelium, low expression of adhesion molecules, as well as low chemokine expression in the tumor and/or aberrant chemokine receptor expression on the $\mathrm{T}$ cells are discussed to hinder the infiltration of effector cells [9]. To overcome these issues, several very specific strategies dependent on the tumor and $\mathrm{T}$ cell type have been developed such as the use of antibodies or homing peptides, which increased activation of the cells but also induced severe adverse events such as cytokine release syndrome or seizures and cerebellar effects [10-12]. In addition, their specificity, short half-time, and high costs may represent an obstacle for wider use [13]. Thus, a safe and targeted approach, applicable to various effector cell types and tumors is of urgent need.

Superparamagnetic iron oxide nanoparticles (SPIONs) have come into focus as magnetically controllable shuttles to deliver drugs specifically to the desired region and sparing healthy tissues, referred to as "Magnetic Drug Targeting (MDT)" [14]. For this, SPIONs loaded with a (chemo-)therapeutic drug, are applied to the tumor supplying vascular system and enriched in the tumor region by application of an external magnetic field. We and others have shown successful targeting and enhanced anti-tumor activity of SPION-loaded chemotherapeutic agents when magnetically accumulated in the tumor region [14-16]. Following the principle of magnetic targeting, it is not only possible to transport active ingredients to a target by magnetic control. Cells can also be loaded with SPIONs and moved to the desired region by an external magnetic field. For that, the SPIONs must either bind to the cell surface or be taken up into the cell. Dendritic cells, stem cells, and endothelial cells have been functionalized with SPIONs and were magnetically guided to the target tissue for tumor vaccination, to control tissue injury or application in regenerative medicine [17-19].

Concerning diagnosis, magnetic nanoparticles can be visualized in magnetic resonance imaging (MRI) and have been used for liver imaging previously. Analogously, SPIONloaded cells can be visualized by MRI, which has been used to track the path of T cells for a better understanding of migration and survival of antigen-specific $\mathrm{T}$ cells under pathophysiological situations [20-22]. Interestingly, for future translation into clinics, the magnetic field coils inherent to clinical MRI scanners can not only be used for tracking but also steering magnetic nanoparticles or nanoparticle-loaded cells into the wanted region [23,24].

To enable their site-directed targeting, lymphocytes such as NK cells and T cells have been previously functionalized with SPIONs [25-32]. Physicochemical factors of the nanoparticles such as surface charge, size, shape, and coating were reported to influence 
nanoparticle uptake and biocompatibility [33]. Since lymphocytes are not phagocytic, their nanoparticle uptake is usually low [34], which might reduce magnetic retention. Positively charged coatings of the SPIONs such as 3-aminopropyl-triethoxysilane can enhance interaction with the negatively charged plasma membrane [31] but might also lead to nanoparticle clusters that can detach and spill from the loaded cells. Moreover, NK cells were loaded with positively charged magnetic nanocomplexes and enabled image-based guiding by MRI after intra-arterial infusion [35]. Another employed strategy was the binding of magnetic nanoclusters onto T cells via a PD-1 antibody, which enabled efficient recruiting of T cells to tumor sites, where the PD- 1 antibody was released and both, together, exerted a synergistic anti-tumor effect [28]. Zupke et al. showed that the loading efficacy of $\mathrm{T}$ cells with nanoparticles strongly depended on nanoparticle concentration, incubation time, and temperature, as well as the presence of serum in the incubation media [36]. The question if SPIONs spill from labeled cells to other cells and the stability of SPIONs in the loaded cells, however, has not been intensively investigated so far.

Besides other challenges, for magnetic guidability the basis is the stable and sufficient loading of SPIONs on or into the $\mathrm{T}$ cells without compromising their viability and effector functions. Here, we investigated, with negatively charged citrate-coated SPI-ONs, how experimental conditions influence nanoparticle uptake and viability of primary human $\mathrm{T}$ cells.

\section{Materials and Methods}

\subsection{Materials}

Cell culture plates were purchased from TPP (Trasadingen, Switzerland). Merck (Darmstadt, Germany) provided the Muse ${ }^{\circledR}$ Count \& Viability Assay Kit. Ringer's solution was acquired from Fresenius Kabi (Bad Homburg, Germany). Hoechst 33342 (Hoe), 1,1'dimethyl-3,3,3',3'-tetramethylindodicarbocyanine iodide (DiIC1(5)), Gibco ${ }^{\mathrm{TM}}$ RPMI medium 1640, GlutaMAX supplement, penicillin-streptomycin solution $5000 \mathrm{U} / \mathrm{mL}, \mathrm{Vy}-$ brandt $^{\mathrm{TM}}$ DiD, Syto16, Fixable Viability Dye eFluor ${ }^{\mathrm{TM}} 450$, CellTrace ${ }^{\mathrm{TM}}$ Violet (CTV), and L-glutamine (200 $\mathrm{mM}$ ) were purchased from Thermo Fisher Scientific (Waltham, MA, USA). Propidium iodide (PI) and phosphate-buffered saline (PBS) were obtained from Sigma-Aldrich (Taufkirchen, Germany), fetal calf serum (FCS), and amphotericin B from Biochrom (Berlin, Germany).

The Human CD3 Fab-TACS Gravity Kit was obtained from IBA (Goettingen, Germany), and the nitric acid $65 \%$ from Carl Roth (Karlsruhe, Germany). The $\mathrm{H}_{2} \mathrm{O}$ used in all experiments was prepared in-house using the Merck Milli- $\mathrm{Q}^{\circledR}$ Direct water purification system (Darmstadt, Germany). Falcon ${ }^{\circledR} 40 \mu \mathrm{m}$ and $70 \mu \mathrm{m}$ cell strainers were purchased from Corning by Life Sciences (Corning, NY, USA) and LabSolute (Renningen, Ger-many). Annexin A5 fluorescein isothiocyanate (FITC) conjugate (AxV-FITC) and recombinant human Interleukin (rhIL)-2 and rhIL-7 were obtained from ImmunoTools (Friesoythe, Germany), the ImmunoCult ${ }^{\mathrm{TM}}$ Human CD3/CD28/CD2 T cell Activator was obtained from Stemcell Technologies (Vancouver, BC, Canada), and the S-Monovettes $10 \mathrm{~mL} 9 \mathrm{NC}$ were obtained from Sarstedt (Nuembrecht, Germany). BD Insyte-W intravenous cannula, 16GA were purchased from BD (Haryana, India). Iron reference standards $(1 \mathrm{~g} / \mathrm{L})$ were purchased from Bernd Kraft GmbH (Duisburg, Germany).

BioLegend (San Diego, CA, USA) provided APC anti-human CD8a, APC Mouse IgG1, k Isotype Control, PerCP/Cy5.5 anti-human CD4, PerCP Mouse IgG1, k Isotype Control, and PE anti-human IL-2. FITC mouse anti-human CD3, Pacific Blue mouse antihuman CD8, Pacific Blue mouse IgG1, k, Isotype Control and FITC Mouse IgG1, k, Isotype Control were obtained from BD Pharmingen (San Jose, CA, USA). Inside Stain Kit, PE anti-human Tumor Necrosis Factor (TNF)- $\alpha$, APC-Vio $770^{\circledR}$ anti-human Interferon (IFN)- $\gamma$ were purchased from Miltenyi Biotec (Bergisch Gladbach, Germany). Ibidi (Gräflingen, Germany) provided $\mu$-Slide I Luer with a channel height of $0.4 \mathrm{~mm}$. The peristaltic pump Ismatec ${ }^{\circledR}$ IPC and PharMed ${ }^{\circledR}$ BPT tubes (2.06 mm inner diameter) were obtained from Cole- 
Parmer GmbH (Wertheim, Germany). Neodymium disc-shaped magnets (5 $\mathrm{mm} \times 5 \mathrm{~mm}$, approximately $400 \mathrm{mT}$ ) were purchased from Webcraft $\mathrm{GmbH}$ (Gottmadingen, Germany).

The Gallios flow cytometer and Kaluza analysis Software $(1.3,2.1)$ were obtained from Beckman Coulter (Brea, CA, USA). The SpectraMax iD3 plate reader was purchased from Molecular Devices (San José, CA, USA).

For the analysis of T cells in transmission electron microscopy (TEM) the following was used: Carl Roth (Karlsruhe, Germany) supplied glutardialdehyde $25 \%$ (for microscopy) in $\mathrm{PO}_{4}$-buffer, ethanol (absolute), acetone (100\% anhydrous), hardener MNA, DPA, glycidyl ether (100 \%), accelerator DMP 30, and $\mathrm{NaOH}$ (1 M). Science Service (Munich, Germany) supplied $\mathrm{OsO}_{4}$, copper grid. Merck (Darmstadt, Germany) supplied $\mathrm{K}_{3}\left(\mathrm{Fe}(\mathrm{Cn})_{6}\right.$, agarose (low melting point), and lead(II)citrate-3-hydrate. Serva (Heidelberg, Germany) supplied uranyl acetate. The following equipment from these companies was used: Emerson (Saint Louis Missouri, United States) Branson 1200 ultra-sonic machine, Leica (Wetzlar, Germany) Ultracut UCT, Zeiss (Oberkochen, Germany) TEM Leo 906, TRS Tröndle (Moorenweis, Germany) CCD camera, ImageSP SysPROG.

\subsection{Synthesis of SPIONs and Physicochemical Characterization}

SPIONs were synthesized based on an adjusted protocol of Elbialy et al. [37] in three batches. Particles were sterilized by filtration through syringe filters with $0.2 \mu \mathrm{m}$ pore size (Sartorius, Goettingen, Germany). Subsequently, SPIONs were analyzed regarding their size, iron content, magnetic susceptibility, and zeta potential according to Mühlberger et al. [26]. The iron content was investigated after a dilution of 1:25 in deionized $\mathrm{H}_{2} \mathrm{O}$ and dissolving in $65 \%$ nitric acid with atomic emission spectroscopy (AES), using the Agilent 4200 MP-AES (Agilent Technologies, Santa Clara, CA, USA) with an iron solution of $1000 \mathrm{mg} / \mathrm{L}$ as an external standard (Bernd Kraft, Duisburg, Germany). Triplicate measurements were performed at a wavelength of $371,993 \mathrm{~nm}$, which were then averaged.

\subsection{Isolation of $T$ Cells from Human Whole Blood}

Human cells were isolated from peripheral human blood obtained from healthy volunteers after informed consent (approved by the ethics committee of the FriedrichAlexander-Universität Erlangen-Nürnberg; reference number 257_14 B). To obtain CD3+ $\mathrm{T}$ cells from citrate-anticoagulated human blood, the CD3 Fab-TACS ${ }^{\mathrm{TM}}$ Gravity Kit was used according to the manufacturer's instructions for freshly drawn blood. Isolated T cells were counted in a MUSE cell Analyzer using the MUSE ${ }^{\circledR}$ Count and Viability assay kit.

\subsection{Determination of T Cell Purity}

To compare the $\mathrm{T}$ cell frequency in whole blood before isolation with the one after isolation, erythrocytes were lysed in $100 \mu \mathrm{L}$ whole blood for $20 \mathrm{~s}$ using $600 \mu \mathrm{L} 0.12 \%$ formic acid ( $\mathrm{pH}$ 2.7). Immediately after lysis, the solution was neutralized with $265 \mu \mathrm{L}$ solution containing $6 \mathrm{~g} / \mathrm{L}$ sodium carbonate, $14.5 \mathrm{~g} / \mathrm{L}$ sodium chloride, and $31.1 \mathrm{~g} / \mathrm{L}$ sodium sulphate ( $\mathrm{pH}$ 11.2). Then, the cells were washed with $1 \mathrm{~mL}$ PBS and centrifuged at $300 \mathrm{rcf}$ for $5 \mathrm{~min}$ at room temperature. Lysed whole blood and freshly isolated T cells were then stained with antibodies against CD3, CD4, CD8, and corresponding isotype controls for $30 \mathrm{~min}$ at $4{ }^{\circ} \mathrm{C}$. Subsequently, the cells were investigated by flow cytometry and the data was analyzed with the Kaluza software (version 2.1).

\subsection{Determination of Cell Viability}

Cell viability was determined in flow cytometry by staining $50 \mu \mathrm{L}$ cell suspension with $250 \mu \mathrm{L}$ of staining mixture for $20 \mathrm{~min}$ at $4{ }^{\circ} \mathrm{C}$. The staining mixture contained $20 \mathrm{nM}$ Hoe, $2 \mu \mathrm{L} / \mathrm{mL}$ AxV-FITC, $4 \mathrm{nM}$ DiIC1(5), and $66.6 \mathrm{ng} / \mathrm{mL}$ PI per ml Ringer's solution. Cells were analyzed in a Gallios flow cytometer. Electric compensation was used to eliminate fluorescence bleed through. Data were analyzed with the Kaluza software (version 2.1). 


\subsection{Colloidal Stability of SPIONs in Various Media and Cellular Nanoparticle Uptake}

If not indicated otherwise, $\mathrm{T}$ cells were cultured in a humidified $5 \% \mathrm{CO}_{2}$ atmosphere at $37^{\circ} \mathrm{C}$ in a standard T cell medium composed of RPMI 1640 medium supplemented with $10 \%$ heat-inactivated (HI) FCS, $2 \%$ penicillin-streptomycin solution, $1 \%$ L-glutamine, and $1 \%$ amphotericin B.

To investigate the colloidal stability dependent on the medium composition, nanoparticles $(0,26.7,53.3,80.0$, and $106.7 \mu \mathrm{g} / \mathrm{mL})$ were incubated in (1) $\mathrm{T}$ cell medium with $10 \%$ FCS or (2) T cell medium with only $2 \%$ FCS or (3) PBS with $2 \%$ FCS overnight in cell culture conditions. The next day, $100 \mu \mathrm{L}$ supernatant of each sample, as well as $100 \mu \mathrm{L}$ of remaining fluid with resuspended SPIONs, was transferred to separate wells of a 96-well plate. The optical density of the samples was measured at $320 \mathrm{~nm}$ in the SpectraMax iD3. To analyze the formation of SPION agglomerates depending on the medium composition, $50 \mu \mathrm{L}$ aliquots of each well were added to $250 \mu \mathrm{L}$ of Ringer's solution and then analyzed by flow cytometry (forward scatter: voltage 500 , gain 5 , discriminator 20 ; side scatter: voltage 550 , gain 10 , discriminator off).

To evaluate the effect of the medium composition on the uptake of SPIONs by T cells, $1 \times 10^{6}$ freshly isolated T cells in $100 \mu \mathrm{L}$ were incubated with SPIONs for one hour. Then, cells were stained for viability as described above, analyzed by flow cytometry, and their iron content was quantified in AES as detailed in Section 2.2.

\subsection{Comparison of Stimulated and Non-Stimulated T Cells}

$2 \times 10^{6}$ of T cells were stimulated in a concentration of $1 \times 10^{6}$ cells per $\mathrm{ml}$ with $30 \mathrm{IU} / \mathrm{mL}$ rhIL-2 and $25 \mu \mathrm{L} / \mathrm{mL} / 1 \times 10^{6}$ cells of Immunocult ${ }^{\mathrm{TM}}$ human CD3/CD28/CD2 $\mathrm{T}$ cell activator. Unstimulated CD3-positive cells in standard $\mathrm{T}$ cell medium served as controls. After $72 \mathrm{~h}, 2 \mathrm{~mL}$ of either the T cell medium only or the T cell medium containing $30 \mathrm{IU} / \mathrm{mL}$ rhIL-2 was added to the controls or stimulated T cells, respectively.

To determine the effects of the stimulation on the viability of the T cells, flow cytometry was performed after $0 \mathrm{~h}$ and $96 \mathrm{~h}$ as described above. Additionally, MUSE cell count and viability analyses were conducted to confirm the flow cytometry results.

\subsection{Determination of Nanoparticle Uptake}

$\mathrm{T}$ cells were stimulated as described in Section 2.7. After the second stimulation at $72 \mathrm{~h}$, $200 \mu \mathrm{L}$ SPION solution was added to the test samples or the controls, respectively. A control was also established, which received only $200 \mu \mathrm{L}$ deionized $\mathrm{H}_{2} \mathrm{O}$ without SPIONs. After an additional $24 \mathrm{~h}$, the $\mathrm{T}$ cells were washed twice with PBS to remove free nanoparticles. The $\mathrm{T}$ cell number was determined via the Muse Cell Analyzer. Cells were then sedimented by centrifugation at $300 \mathrm{rcf}$ for $5 \mathrm{~min}$. After discarding the supernatant, the pellets were dried at $95^{\circ} \mathrm{C}, 300 \mathrm{rpm}$ for $30 \mathrm{~min}$ in a $1.5 \mathrm{~mL}$ Eppendorf tube, before they were lysed with $100 \mu \mathrm{L}$ nitric acid at $95^{\circ} \mathrm{C}, 750 \mathrm{rpm}$ for $15 \mathrm{~min}$. $900 \mu \mathrm{L}$ of water was added, followed by measurement of their iron concentration by AES.

The long-term stability of the ingested SPIONs was also investigated. T cells were loaded with $80 \mu \mathrm{g} \mathrm{Fe} / \mathrm{mL}$ SPIONs overnight, controls received only deionized $\mathrm{H}_{2} \mathrm{O}$. The cells were then seeded at a concentration of $2 \times 10^{6}$ cells in $2 \mathrm{~mL}$ of T cell medium. $10 \mathrm{ng} / \mathrm{mL}$ IL-7 was added to the T cell medium to increase long-term survival. After $24 \mathrm{~h}$, $48 \mathrm{~h}$, and $72 \mathrm{~h}$, the cells were collected, washed three times to remove any unbound iron, and cell count was determined using the MUSE Cell Analyzer. Samples were dried at $95^{\circ} \mathrm{C}$ for $30 \mathrm{~min}$, lysed with $50 \mu \mathrm{L} \mathrm{HNO}_{3}$ at $95^{\circ} \mathrm{C}$ for $15 \mathrm{~min}$, and dissolved in $450 \mu \mathrm{L}$ deionized $\mathrm{H}_{2} \mathrm{O}$. The iron content was determined with AES and the pg iron per cell was calculated by dividing the iron amount by the cell number.

\subsection{SPION Exchange with Non-Loaded T Cells}

$2 \mathrm{~mL}$ of $1 \times 10^{6} \mathrm{CD} 3+\mathrm{T}$ cells per $1 \mathrm{~mL}$ in T cell medium were seeded in 12-well plates, half of them were incubated with SPIONs overnight; the control group was treated the same way with deionized $\mathrm{H}_{2} \mathrm{O}$. The next day, nanoparticles were washed from the 
samples at $300 \mathrm{rcf}$ for $5 \mathrm{~min}$ at room temperature. Loaded T cells were stained with FITC anti-human CD3 antibody for $30 \mathrm{~min}$ at $4{ }^{\circ} \mathrm{C}$ with a working solution of 1:200 in $\mathrm{T}$ cell medium, were washed two times and resuspended. Non-loaded cells were resuspended in medium and placed into 96-well plates. Triplicates of $100 \mu \mathrm{L}$ pure non-loaded T cells, triplicates of $100 \mu \mathrm{L}$ loaded T cells, and triplicates with mixed $50 \mu \mathrm{L}$ non-loaded and $50 \mu \mathrm{L}$ stained loaded $\mathrm{T}$ cells were placed into 96-well plates and incubated for three hours in an incubator at $37^{\circ} \mathrm{C}$. All samples were placed in the flow cytometer and the side scatter was analyzed. Populations of non-loaded and loaded CD3+ T cells were differentiated by a CD3 stain.

To investigate the long-term stability of the ingested iron in the cells, $\mathrm{T}$ cells were stained with $5 \mu \mathrm{M}$ of CTV for $30 \mathrm{~min}$ at $37^{\circ} \mathrm{C}$ and then loaded with $80 \mu \mathrm{g}$ Fe/mL SPIONs overnight as described above; an unstained control received only deionized $\mathrm{H}_{2} \mathrm{O}$. The cells were then washed to remove excess particles and seeded in a 12-well plate at a concentration of $1 \times 10^{6}$ cells in $2 \mathrm{~mL}$ of T cell medium. IL-7 was added to the T cell medium at a concentration of $10 \mathrm{ng} / \mathrm{mL}$, to increase the long-term survival. The exchange between loaded and non-loaded cells was investigated by the seeding of $0.5 \times 10^{6}$ of each loaded and non-loaded T cells in $2 \mathrm{~mL}$ of T cell medium. After $24 \mathrm{~h}, 48 \mathrm{~h}$, and $72 \mathrm{~h}$, cells were collected, stained with $2 \mu \mathrm{L} / \mathrm{mL}$ AxV-FITC and $66.6 \mathrm{ng} / \mathrm{mL}$ PI for $20 \mathrm{~min}$ at $4{ }^{\circ} \mathrm{C}$, and then analyzed by flow cytometry.

\subsection{Transmission Electronic Microscopy}

For determination of the incorporated amount of SPIONs, transmission electronic microscopy (TEM) was performed. For that, T cells were isolated and incubated for $72 \mathrm{~h}$ in $\mathrm{T}$ cell medium. Afterwards, SPIONs were added to $8 \times 10^{6} \mathrm{~T}$ cells per sample for $24 \mathrm{~h}$ to receive $2667 \mu \mathrm{g} / \mathrm{mL}$ or $80 \mu \mathrm{g} / \mathrm{mL}$ of iron. Cells that received only $\mathrm{H}_{2} \mathrm{O}$ without SPIONs served as controls. Subsequently, the cells were washed three times with PBS whereupon they were fixated in $2.5 \%$ glutaraldehyde in $0.1 \mathrm{M} \mathrm{PO}_{4}$ buffer for $4 \mathrm{~h}$, subsequently washed 3 times with $0.1 \mathrm{M} \mathrm{PO}_{4}$ buffer and left overnight at $4{ }^{\circ} \mathrm{C}$. The staining of the cells for TEM was performed with $1 \%$ osmium treta oxide $\left(\mathrm{OsO}_{4}\right)$ in $3 \%$ potassium ferricyanide $\left(\mathrm{K}_{3}\left(\mathrm{Fe}(\mathrm{Cn})_{6}\right)\right.$ for $2 \mathrm{~h}$ at room temperature $(\mathrm{RT})$, and additionally washing the stained cells with $0.1 \mathrm{M} \mathrm{PO}_{4}$ buffer overnight at $4{ }^{\circ} \mathrm{C}$. Before embedding the cells in Epon resin, the cells were transferred into a matrix of $2 \%$ agarose (low melting point) in $0.1 \mathrm{M} \mathrm{PO}_{4}$ buffer in an Eppendorf reaction tube overnight. For Epon resin embedding, the cells were dehydrated in agarose through an ethanol step and finally transferred to Epon using acetone and an acetone-epon mixture, followed by a polymerization step for $48 \mathrm{~h}$ at $60{ }^{\circ} \mathrm{C}$. Ultra-thin sections of approximately $50 \mathrm{~nm}$ section thickness of the samples were prepared with the Leica Ultracut UCT and placed on copper grids. These ultra-thin sections were then first contrasted with lead citrate for $10 \mathrm{~min}$ and then with uranyl acetate for a further $10 \mathrm{~min}$. The images were taken with the Zeiss TEM 906 LEO (from Zeiss) with a CCD-camera residual light amplifier from A. Tröndle, TRS, and the software ImageSP SYS Prog, TRS. The images were taken at an acceleration voltage of $80 \mathrm{kV}$ and a magnification of 12,930-fold.

\subsection{Magnetic Accumulation of SPION-Loaded T Cells under Dynamic Conditions}

The magnetic attractability of CD3+ T cells after SPION-loading was evaluated under dynamic conditions. To imitate blood flow, a peristaltic pump was used to move SPIONloaded cells through slides to which Neodymium disc shape magnets $(5 \mathrm{~mm} \times 5 \mathrm{~mm}$, approximately $400 \mathrm{mT}$ ) were attached. Unloaded cells and slides without magnets served as controls. After $1 \mathrm{~h}$ of pumping, magnetically accumulated cells were stained with the Hoechst 33,342 stain. Images were taken on a Zeiss Axio Observer Z1 fluorescence microscope (Carl Zeiss AG, Oberkochen, Germany). Subsequently, pictures were analyzed using the Image J software (version 1.52a). 


\subsection{2. $T$ Cell Activation and Proliferation after Polyclonal Stimulation}

The $\mathrm{T}$ cells were investigated for cytokine production after stimulation. T cells were isolated and loaded as described above and stimulated with $25 \mu \mathrm{L}$ per $1 \times 10^{6}$ cells per $1 \mathrm{~mL}$ ImmunoCult human CD3/CD28/CD2 T-cell activator mix, however, no IL-2 was added. After $24 \mathrm{~h}$, the T cells were stained for CD4 and CD8 for $30 \mathrm{~min}$ at $4{ }^{\circ} \mathrm{C}$, in order to distinguish T cell subclasses. Afterwards, the cells were fixated and permeabilized with the inside stain kit. The fixation was performed at room temperature for 20 min with $100 \mu \mathrm{L}$ of Inside Fix. Cells were then permeabilized for $30 \mathrm{~min}$ at $4{ }^{\circ} \mathrm{C}$ with the addition of antibodies against TNF- $\alpha$, IF- $\gamma$, and IL-2. Subsequently, the cells were analyzed by flow cytometry.

\subsection{Data Analysis and Statistics}

Data were prcessed in Microsoft Excel (Microsoft, Redmond, WA, USA). Statistical analysis and graph creation were performed with GraphPad PRISM 9.0.2 from GraphPad Software, Inc. (San Diego, CA, USA). For statistical significance, $p$-values $\leq 0.05$ were considered.

\section{Results}

\subsection{Physicochemical Characterization of SPIONs}

Magnetic susceptibility, hydrodynamic Z-average size, and zeta potential of three independently synthesized batches of SPIONs were investigated (Table 1). The magnetic susceptibility of the particles normalized to an iron concentration of $1 \mathrm{mg} / \mathrm{mL}$ for the purpose of comparison was determined to be ranging from $4.08 \times 10^{-3}$ to $4.12 \times 10^{-3}$. The hydrodynamic Z-average size of the nanoparticles was in mean $52 \mathrm{~nm}$ to $58 \mathrm{~nm}$. In accordance, the polydispersity index (PDI) in water was 0.143 to 0.152 . The zeta potential ranged from $-48.5 \mathrm{mV}$ to $-53.7 \mathrm{mV}$ in deionized $\mathrm{H}_{2} \mathrm{O}$ with a $\mathrm{pH}$ of 7.3.

Table 1. Physicochemical characterization of SPIONs.

\begin{tabular}{cccc}
\hline Physicochemical Feature & Batch $\mathbf{1}$ & Batch $\mathbf{2}$ & Batch 3 \\
\hline Magnetic susceptibility $\left(10^{-3}\right)$ & $4.08 \pm 0.00$ & $4.12 \pm 0.00$ & $4.10 \pm 0.00$ \\
Z-average size (nm) in $\mathrm{H}_{2} \mathrm{O}$ & $58 \pm 0.1$ & $52 \pm 0.1$ & $53 \pm 0.2$ \\
Polydispersity index (PDI) & $0.143 \pm 0.005$ & $0.151 \pm 0.08$ & $0.152 \pm 0.07$ \\
Zeta potential (mV) at pH 7.3 & $-48.5 \pm 0.5$ & $-53.7 \pm 0.4$ & $-51.8 \pm 0.3$ \\
\hline
\end{tabular}

\subsection{Colloidal Stability of SPIONs in Cell Culture Medium}

Since the protein corona is known to play a crucial role in nanoparticle uptake, we reduced the FCS amount from $10 \%$ to $2 \%$ in the cell culture medium in order to increase cellular nanoparticles loading. Experiments were additionally performed in $2 \%$ FCS in PBS. To determine the colloidal stability of SPIONs in the above-mentioned media, the nanoparticles were incubated overnight to allow them to agglomerate and sediment. On the next day, the nanoparticle suspensions were analyzed for agglomerations. In the medium with only $2 \%$ FCS, already macroscopically nanoparticle agglomerations were visible in a dose-dependent manner. In PBS with $2 \%$ FCS and medium with $10 \%$ FCS, we found no obvious larger nanoparticle sedimentations (Figure 1A). To analyze smaller agglomerations, which were not visible to the naked eye, we measured the absorption of the supernatant of sedimented or resuspended nanoparticle suspensions, respectively. Recording of the spectrum (250-500 nm) of nanoparticle dilutions revealed an optimal wavelength for the detection of SPIONs at $320 \mathrm{~nm}$ (Figure 1B). In the case of complete colloidal stability, the absorption of sedimented and resuspended samples should be equal. SPIONs in T cell medium containing 10\% FCS and 2\% FCS in PBS revealed the best colloidal stability as determined by absorption measurements of the supernatant of the sedimented and resuspended samples. Thus, absorption values of the supernatant of sedimented and resuspended samples increased dose-dependently and were not dramatically different between both. In contrast, the medium containing only $2 \%$ FCS induced nanoparticle 
agglomeration and sedimentation, causing large differences in the optical density values of the supernatants of sedimented and resuspended samples. The resuspended samples induced a dose-dependent absorption, whereas already in the smallest tested concentration the values of the sedimented and resuspended samples were different (Figure 1C). Analyzing the agglomerations by flow cytometry supported this conclusion: only in the T cell medium with $2 \%$ FCS nanoparticle agglomerations were detected by their relative size (forward scatter) and granularity (side scatter). In the other solutions, the nanoparticles were colloidally stable and the nanoparticle sizes were below the detection limit (Figure 1D).

A

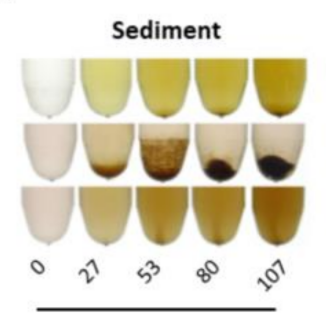

$\mu \mathrm{Fe} / \mathrm{ml}$

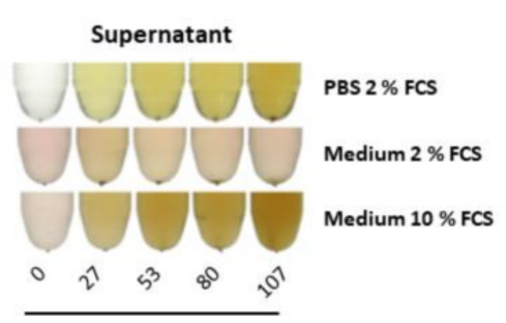

$\mu \mathrm{Fe} / \mathrm{ml}$
B

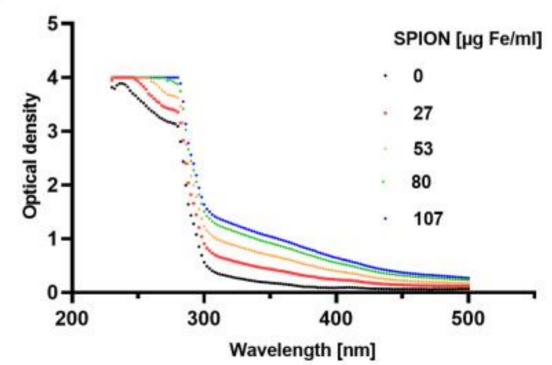

C
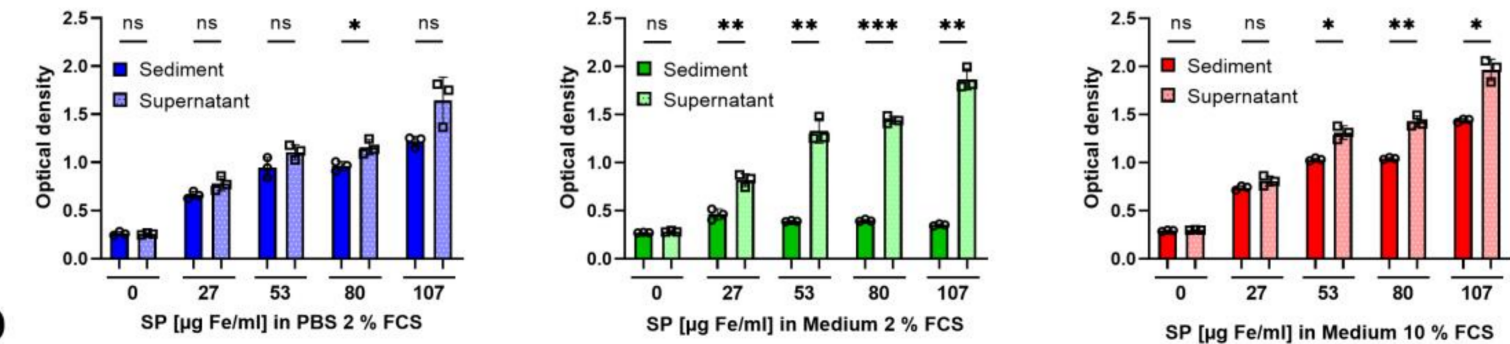

SP $[\mu \mathrm{g} \mathrm{Fe} / \mathrm{ml}]$ in Medium $10 \%$ FCS
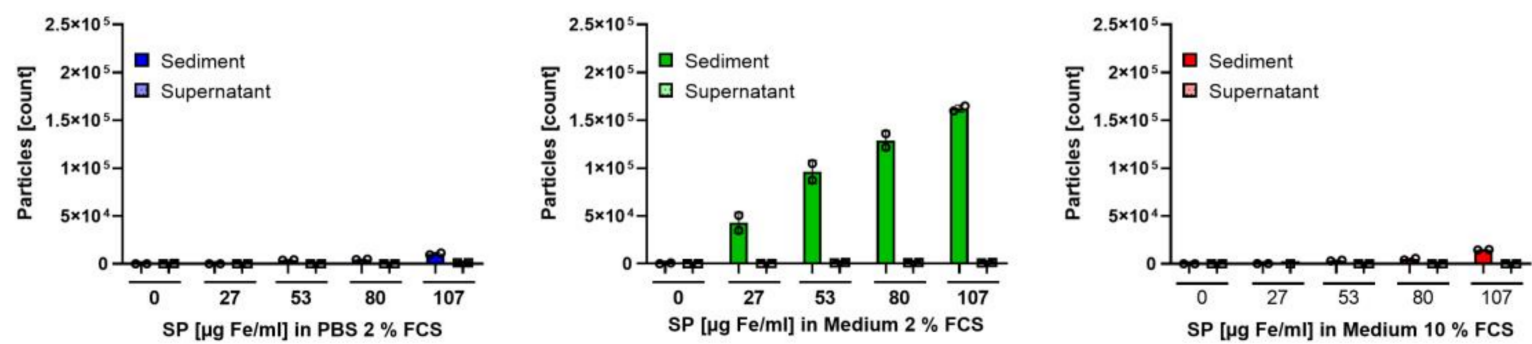

Figure 1. Colloidal stability of SPIONs in various media. SPIONs were incubated overnight in PBS with $2 \%$ FCS or RPMI cell culture medium containing $2 \%$ or $10 \%$ FCS, respectively. (A) Macroscopic pictures of SPIONs diluted in PBS supplemented with $2 \%$ FCS or T cell medium with $2 \%$ or $10 \%$ FCS, respectively. (B) Spectrum of SPIONs diluted in RPMI with $10 \%$ FCS. (C,D) T cell medium with $10 \%$ FCS is depicted in red, while T cell medium with $2 \%$ FCS is shown in green. PBS supplemented with 2\% FCS is depicted in blue. (C) Optical density at $320 \mathrm{~nm}$ of the supernatant of sedimented or resuspended samples. (D) Supernatant or sediment was analyzed in flow cytometry for agglomerations. Shown are the mean values of triplicates (C) or duplicates (D) with standard deviations. Significances were calculated using unpaired t-test with Welch's correction; ${ }^{*} p \leq 0.05 ;{ }^{* *} p \leq 0.01 ;{ }^{* * *} p \leq 0.001$. ns: not significant, SP: SPIONs.

\subsection{Influence of Medium Composition on SPION-Loading of T Cells}

T cell isolation via IBA gravity columns resulted in a CD3+ T cell purity of $91.5 \% \pm 1.1 \%$ compared to the portion of CD3+ T cells of 34.9\% $\pm 3.9 \%$ in whole blood (Figure S1). To achieve magnetic guidability of the cells by loading with SPIONs, a sufficient amount of iron per cell is crucial. Based on previous data by Mühlberger et al. [27], we selected $80 \mu \mathrm{g} / \mathrm{mL}$ as the optimal iron concentration for the loading of T cells. Similar to the loading strategy of Sanz-Ortega [31], we reduced the medium volume, resulting in a cell count of 
$1 \times 10^{6}$ cells in $100 \mu \mathrm{L}$ of medium or PBS in the presence of $80 \mu \mathrm{g} / \mathrm{mL}$ SPIONs for $1 \mathrm{~h}$ to enhance contact of cells with the nanoparticles.

Subsequently, cells were washed, counted, and the amount of iron was determined from the cell lysates using AES. Cell count and viability were directly (without washing) determined by flow cytometry after staining for apoptosis and necrosis using AxV-FITC and PI (Figure 2A). AxV-FITC stains phosphatidylserine which is exposed on the outer surface of the cells in apoptosis. Counterstaining with the plasma-membrane impermeable dye PI detects necrotic cells. Thus, AxV-FITC-/PI- cells are considered viable, AxV-FITC+/PIcells apoptotic, and PI+ cells necrotic.

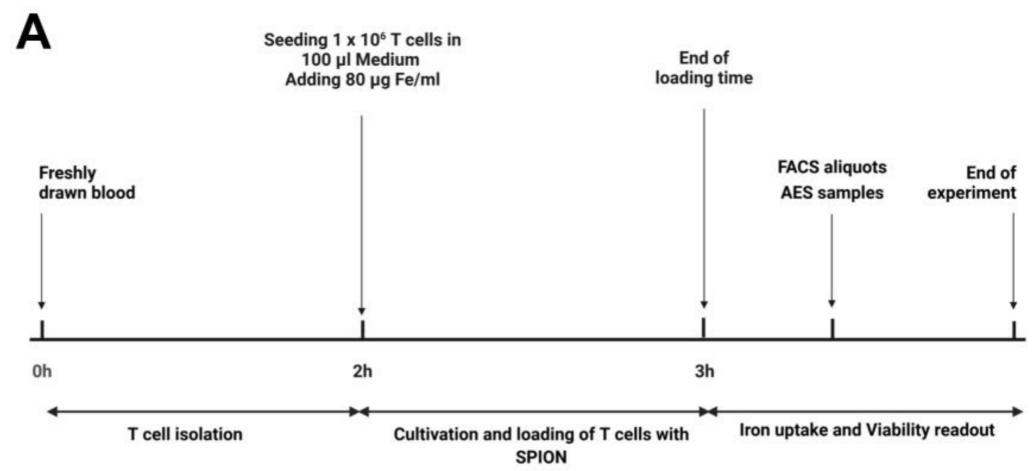

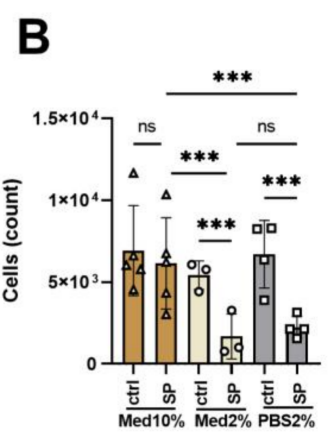

D

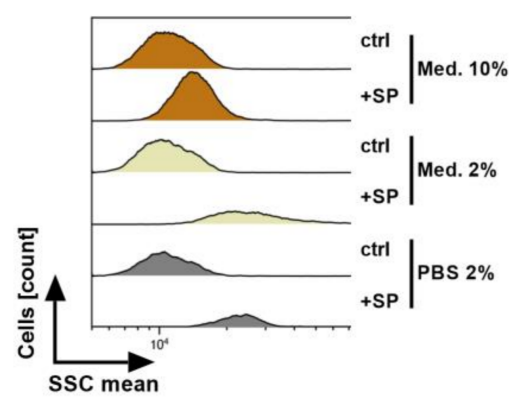

C
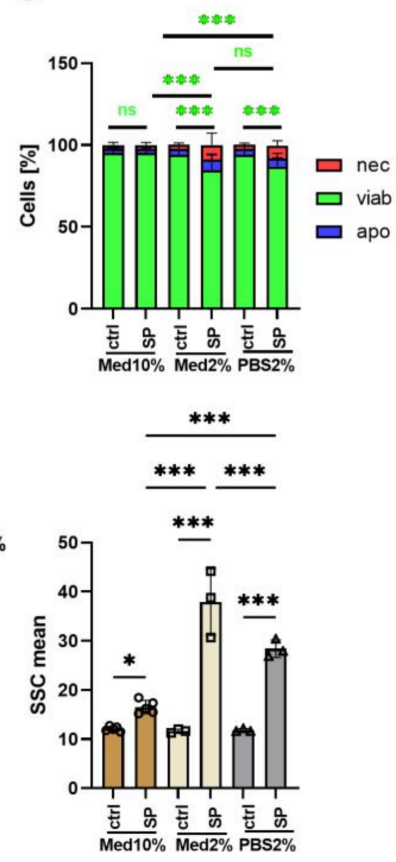

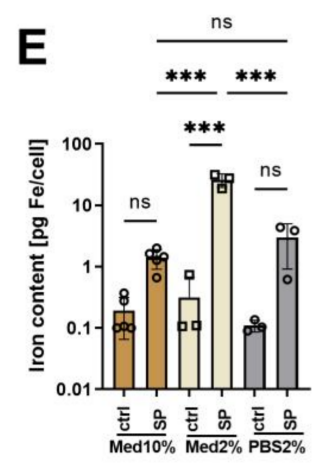

Figure 2. Influence of medium composition on SPION-loading of T cells. (A) Experimental setup. (B) Determination of the cell count by flow cytometry. (C) The viability of the cells was determined by AxV-FITC and PI staining in flow cytometry. AxV-FITC-/PI- cells were considered viable, AxVFITC+/PI- apoptotic, and PI+ cells necrotic. (D) Estimation of cellular nanoparticle loading by analysis of the side scatter increase of viable cells by flow cytometry. (E) Cellular iron content [pg $\mathrm{Fe} /$ cell] was determined by atomic emission spectroscopy of cell lysates. (B-E) Experiments were performed in triplicates of $\mathrm{T}$ cells from 3-5 donors. Shown are the mean values with standard deviations. Significances were calculated with a 2-way ANOVA test with a Tukey post hoc test; ${ }^{*} p \leq 0.05 ;{ }^{* *} p \leq 0.001$. ctrl: control; SSC: side scatter; med: medium; ns: not significant; nec: necrotic; apo: apoptotic; viab: viable. 
With the medium containing 10\% FCS, the cell count was not reduced in the presence of SPIONs. In contrast, SPIONs in both medium or PBS containing $2 \%$ FCS reduced the cell count dramatically (Figure 2B), which might be due to iron overload and rupture of cells. The majority of the residual cells, however, were viable (AxV-FITC-/PI-) (Figure 2C).

As shown by Friedrich et al., nanoparticle uptake was accompanied by an increase of side scatter by flow cytometry [38], serving as a marker to estimate SPION-loading of the cells. Since cell death processes also cause the alteration of cell morphology, we gated only on viable cells based on their AxV-FITC and PI negativity. In RPMI medium with 2\% FCS, in which the nanoparticles agglomerated, the cells showed the largest side scatter increase. In PBS containing $2 \%$ FCS, in which the nanoparticles were colloidally stable, the side scatter increase was smaller, and in medium with 10\% FCS hardly detectable (Figure 2D). We analyzed the iron amount in the cell lysates using AES and calculating the iron amount in relation to the cell count. In line with the side scatter data, we achieved the highest iron values per cell for T cells in medium with $2 \%$ FCS with $26.03 \mathrm{pg} \pm 5.32 \mathrm{pg}$ iron per cell, which might be due to nanoparticle agglomerations in the cell lysates. T cell loading in PBS with $2 \%$ FCS resulted in $2.96 \pm 1.67$ pg iron per cell. Cells in the medium with $10 \%$ FCS contained only $1.40 \pm 0.44$ pg iron per cell (Figure $2 \mathrm{E}$ ).

\subsection{Influence of Polyclonal Stimulation on SPION-Loading of T Cells}

Previously, it has been shown that uptake of nanoparticles by cells is dependent on the cell cycle state, whereas uptake in G2/M was stronger than in the S and G0/G1 phase, respectively [39]. In order to increase nanoparticle uptake by cells, we aimed to foster the division of the cells by polyclonal primary and costimulatory stimulation using CD3/CD28/CD2 beads in the presence of $30 \mathrm{IU} / \mathrm{mL}$ rhIL-2 for $72 \mathrm{~h}$ (Figure 3A). Then, cells were re-stimulated with $30 \mathrm{IU} / \mathrm{mL}$ rhIL-2 for another $24 \mathrm{~h}$. At this time point, $80 \mu \mathrm{g} / \mathrm{mL}$ SPIONs were added as well. Then, after $24 \mathrm{~h}$ incubation with SPIONs and an overall $96 \mathrm{~h}$ of stimulation, viability and iron uptake were determined by flow cytometry and AES, respectively. At this time point, the stimulated T cells were at the cell division stage. Unstimulated cells served as controls.

Flow cytometry revealed that with stimulation the cell count increased from $5.038 \pm 1.637$ to $12.154 \pm 2.865$ cells, whereas the presence of nanoparticles had no influence on the cell count after stimulation (4.932 \pm 1.537 to $13.004 \pm 3.037$ cells) (Figure 3B). The cell viability, however, was reduced by the stimulation from $75.8 \% \pm 9.8 \%$ to $62.4 \% \pm 8.0 \%$. The presence of SPIONs further reduced the cell viability of non-stimulated and stimulated cells to $71.8 \% \pm 10.8 \%$ and $52.9 \% \pm 8.0 \%$, respectively (Figure $3 C$ ).

The side scatter of non-stimulated cells increased from $11.67 \pm 0.53$ to $16.17 \pm 1.17$ in the presence of nanoparticles. For stimulated cells, the side scatter of the cells was generally higher, possibly because of alterations in morphology due to the proliferation. Nonetheless, incubation with nanoparticles further significantly increased it from $31.58 \pm 0.64$ to $32.5 \pm 0.89$ (Figure 3D). Determination of the iron content in the cell pellets via AES and calculation of the iron content per cell confirmed the nanoparticle loading of the cells in the presence of SPIONs. Interestingly, however, we saw no significant differences in the cellular iron amount dependent on the polyclonal stimulation of the cells. We observed $0.976 \pm 0.43 \mathrm{pg}$ Fe/cell for unstimulated and $1.03 \pm 0.33 \mathrm{pg}$ Fe/cell for stimulated cells (Figure 3E).

\subsection{SPION-Loaded T Cells Do Not Exchange Nanoparticles with Non-Loaded T Cells}

After nanoparticle loading, it is mandatory that SPIONs are not released from the cells or exchanged with other cells, to minimize loss of magnetic controllability, spill over to formerly non-loaded cells, and the bias of other cells getting also magnetically attracted.

Transmission electron microscopy of the unstimulated cells revealed both the binding of the SPIONs to the plasma membrane as well as internalization into vesicles (Figure 4A). With $27 \mu \mathrm{g} / \mathrm{mL}$ of SPIONs, most of the nanoparticles were located intracellularly in vesicles. Only some particles were attached to the plasma membrane. With $80 \mu \mathrm{g} / \mathrm{mL}$, obviously 
more nanoparticles were associated with the plasma membrane. These nanoparticles seemed to be tightly attached in a uniform layer at one side of the cell. In the magnification (Figure $4 \mathrm{~A}$, picture 3), the formation of a membrane invagination with SPIONs is visible.
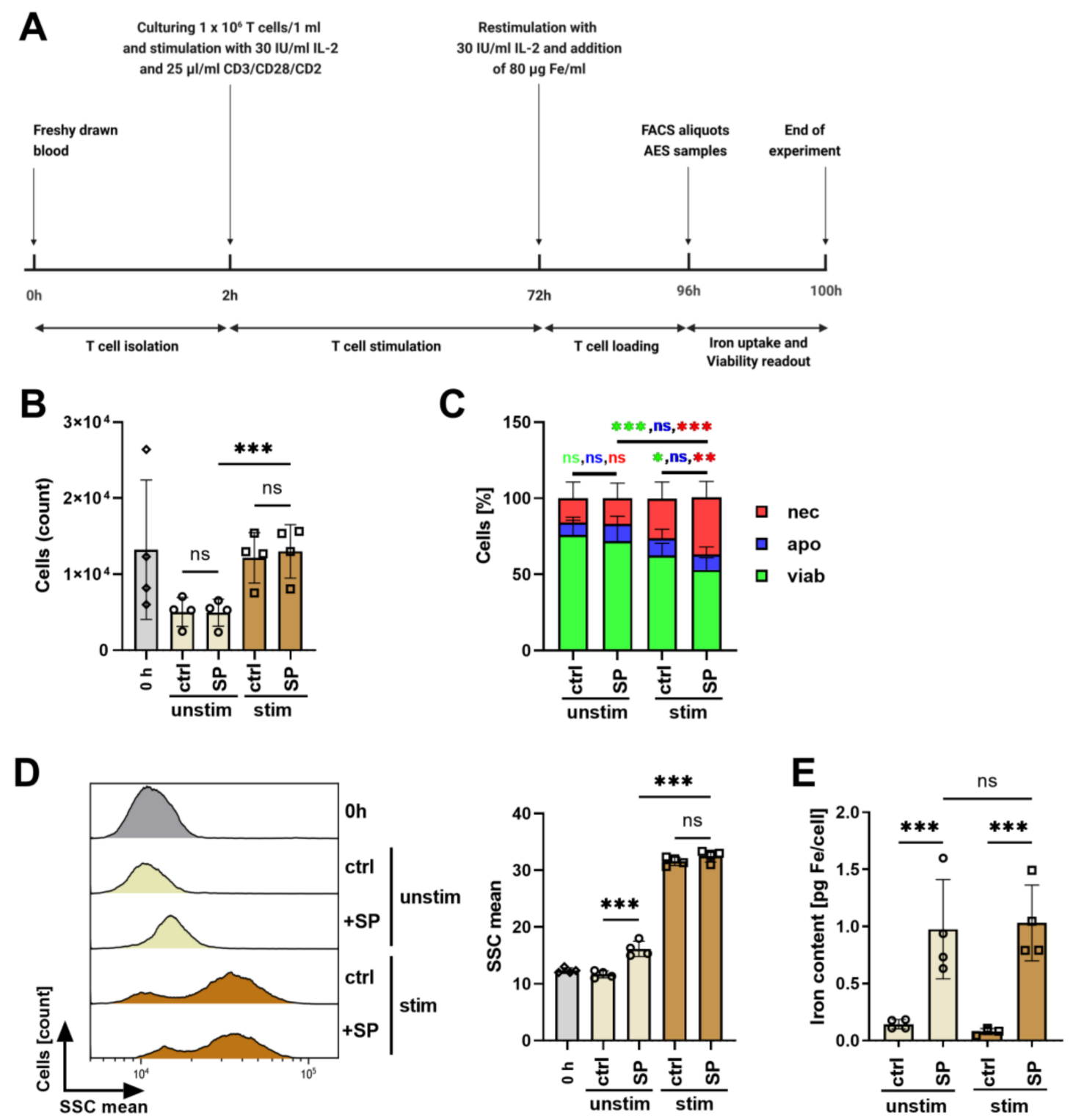

Figure 3. Influence of $\mathrm{T}$ cell stimulation on nanoparticle uptake. (A) Experimental setup. $1 \times 10^{6} \mathrm{CD} 3+\mathrm{T}$ cells in $1 \mathrm{~mL} \mathrm{~T}$ cell medium were stimulated for $72 \mathrm{~h}$ and then re-stimulated and incubated with $80 \mu \mathrm{g} / \mathrm{mL}$ SPIONs for $24 \mathrm{~h}$. Unstimulated and/or cells without SPIONs served as controls. Subsequently, cells were analyzed by flow cytometry and atomic emission spectroscopy (AES). Determination of cell count (B) and viability (C) in flow cytometry. AxV-FITC-/PI- cells were considered viable, AxV-FITC+/PI- cells apoptotic, and PI+ cells necrotic. (D) Side Scatter (SSC) increase of AxV-FITC-/PI- cells indicates nanoparticle uptake. E) Determination of the iron amount (pg/cell) by AES. (B-E) Experiments were performed in triplicates of $\mathrm{T}$ cells from four donors. Shown are the mean values with standard deviations. Significance was estimated by a 2-way ANOVA with a Tukey post hoc test; ${ }^{*} p \leq 0.05 ;{ }^{* *} p \leq 0.01 ;{ }^{* *} p \leq 0.001$. ctrl: control; ns: not significant; SP: SPIONs, stim: stimulated; unstim: unstimulated; nec: necrotic; apo: apoptotic; viab: viable. 
A
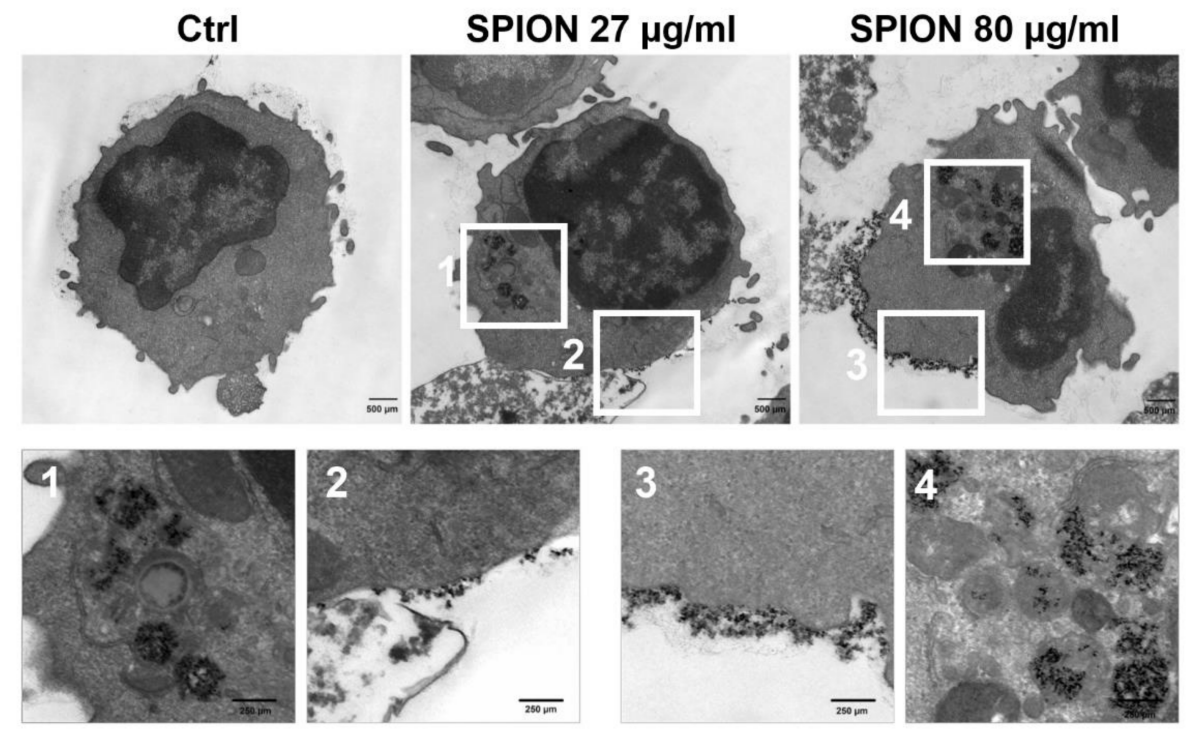

B
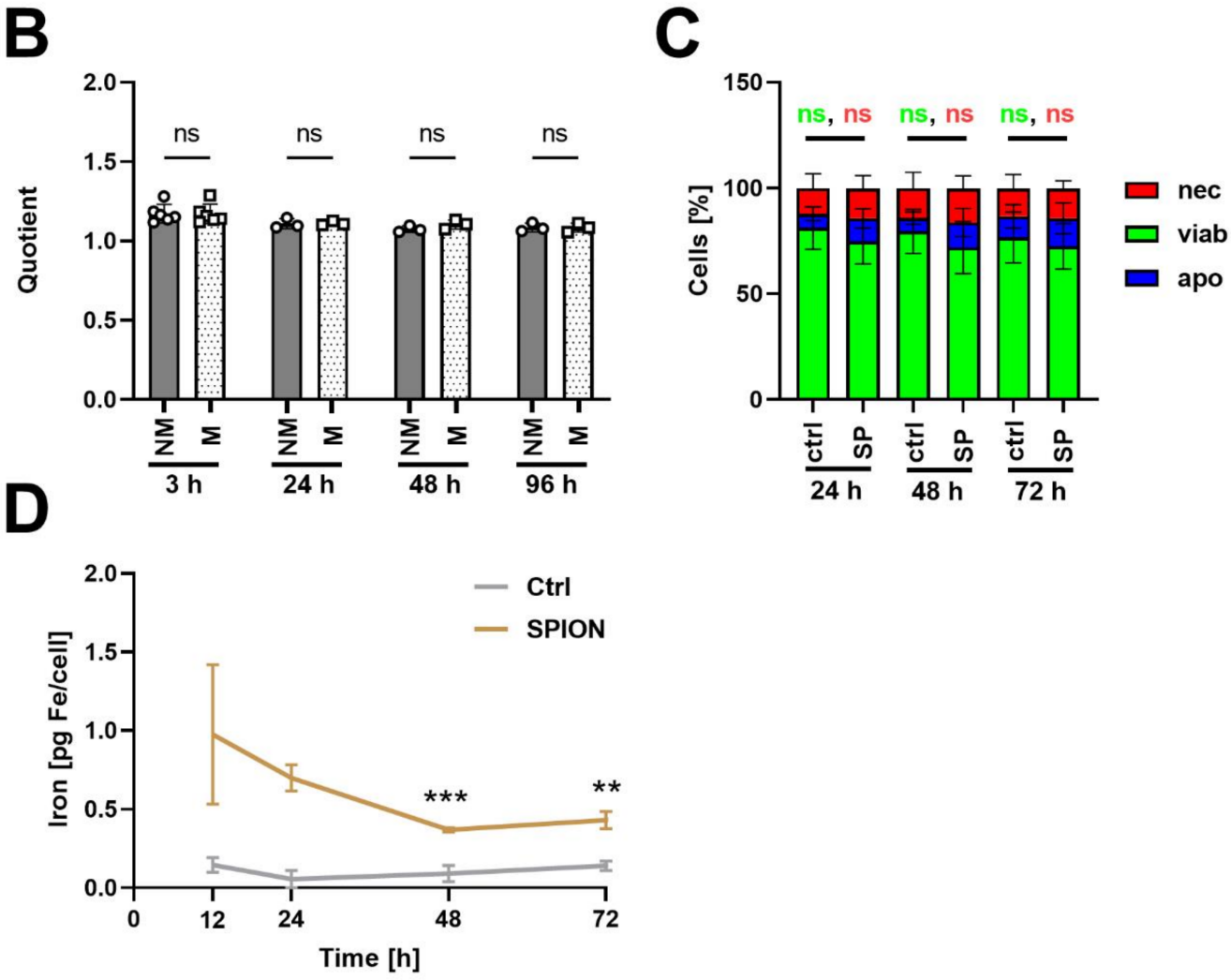

Figure 4. SPIONs were not exchanged between loaded and non-loaded CD3+ T cells. (A) Subcellular localization of SPIONs determined by TEM. Scale bars depict $500 \mu \mathrm{m}$ (upper row) and $250 \mu \mathrm{m}$ (lower row). Squares indicate areas with SPION-loading in T cells. $($ B $)$ Isolated CD3+ T cells $\left(1 \times 10^{6}\right.$ cells $\left./ \mathrm{mL}\right)$ were loaded with $80 \mu \mathrm{g} \mathrm{Fe} / \mathrm{mL}$ SPIONs overnight and stained for CD3 or CTV; non-loaded T cells served as controls. Side scatter values were used for estimation of nanoparticle uptake of SPION-loaded and non-loaded cells. A quotient was calculated by division of the SSC of loaded T cells with that of non-loaded T cells of the same donor at the same time point. (C) Cell viability of SPION-loaded cells. Cells were stained with AxV-FITC and PI. Ax-FITC-/PI- cells were considered viable (viab), Ax-FITC+/PI- apoptotic (apo), and PI+ necrotic (nec). (D) Iron content per cell as determined by atomic emission spectroscopy and division through cell count. Shown are the mean values with standard deviations. Significances were estimated using an unpaired test with Welch's correction; ${ }^{* *} p \leq 0.01,{ }^{* * *} p \leq 0.001$; ctrl: control, SP: SPIONs, NM: not mixed, M: mixed. 
To investigate nanoparticle release from SPION-loaded T cells, cells were loaded overnight with $80 \mu \mathrm{g} \mathrm{Fe} / \mathrm{mL}$ SPIONs and stained for CD3 or with CTV for identification by flow cytometry. Subsequently, we mixed loaded $\mathrm{T}$ cells with non-loaded $\mathrm{T}$ cells and analyzed them after $3 \mathrm{~h}, 24 \mathrm{~h}, 48 \mathrm{~h}$, and $72 \mathrm{~h}$ by flow cytometry regarding SSC increase. Non-loaded T cells and loaded T cells in separate tubes served as controls. For comparison between the time points, a quotient was calculated from the SSC of loaded T cells divided by the SSC of unloaded T cells from the same donor at the same time point. The quotients of non-mixed and mixed samples were not significantly different at each time point (Figure 4B), indicating that nanoparticles were not exchanges between loaded and formerly non-loaded cells. In parallel, we determined the viability after $24 \mathrm{~h}, 48 \mathrm{~h}$, or $72 \mathrm{~h}$ after loading by AxV-FITC and PI staining. As depicted in Figure 4C, after $24 \mathrm{~h} \mathrm{81.1 \% \pm 10.1 \%}$ of unloaded $\mathrm{T}$ cells were still viable compared to $74.7 \% \pm 10.5 \%$ of loaded $\mathrm{T}$ cells. This slightly reduced viability was also detectable after $48 \mathrm{~h}$ (non-loaded: $79.5 \% \pm 10.4 \%$, loaded: $71.9 \% \pm 12.4 \%$ ) and $72 \mathrm{~h}$ (non-loaded: $76.7 \% \pm 12.0 \%$, loaded $72.5 \% \pm 10.8 \%$ ), however was not significant (Figure 4C). Furthermore, the iron content per cell after $24 \mathrm{~h}, 48 \mathrm{~h}$, and $72 \mathrm{~h}$ was determined by AES. Starting with an iron content around $1 \mathrm{pg} / \mathrm{cell}$ at $12 \mathrm{~h}$ after loading, the iron amount was reduced to $0.5 \mu \mathrm{g} / \mathrm{mL}$ at $48 \mathrm{~h}$ until it remained constant (Figure 4D).

\subsection{Loading of T Cells with SPIONs Allows Magnetic Enrichment under Dynamic Conditions}

The magnetic attractability of CD3+ T cells after SPION-loading was evaluated under dynamic conditions. To imitate blood flow in a physiological vascular system, a peristaltic pump was used to move SPION-loaded cells through slides to which magnets were attached. Non-loaded cells and slides without magnets served as controls (Figure 5A). The catching of SPION-loaded cells (containing roughly 1 pg iron/cell) was visible even macroscopically. After $1 \mathrm{~h}$ of pumping, magnetically accumulated cells were analyzed by fluorescence microscopy by Hoechst staining. For cells without SPION-loading, no cell accumulation was detected. With SPION loading, the numbers of cells increased from $62 \pm 90$ to $2188 \pm 186$ (stimulation) in the presence of a magnet, proving their magnetic attractability (Figure 5B-D).

A

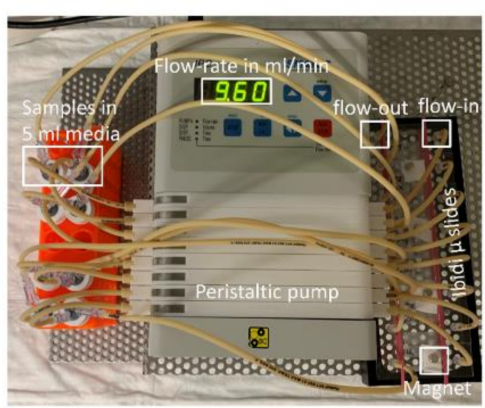

C

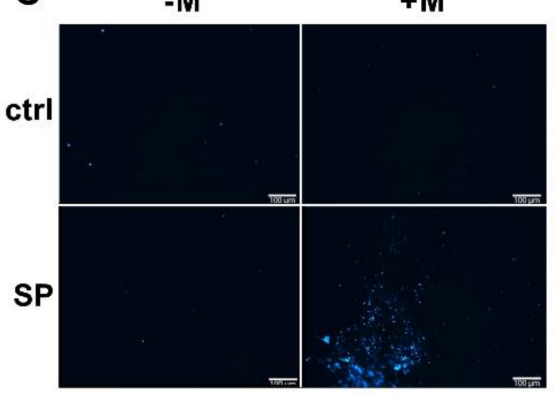

B

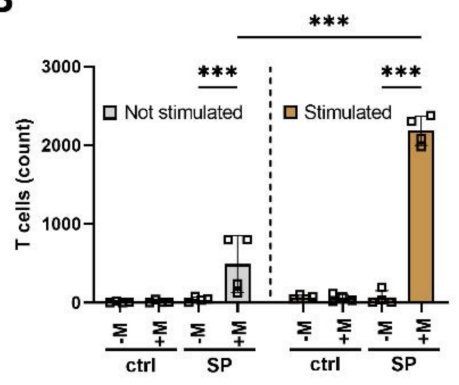

D

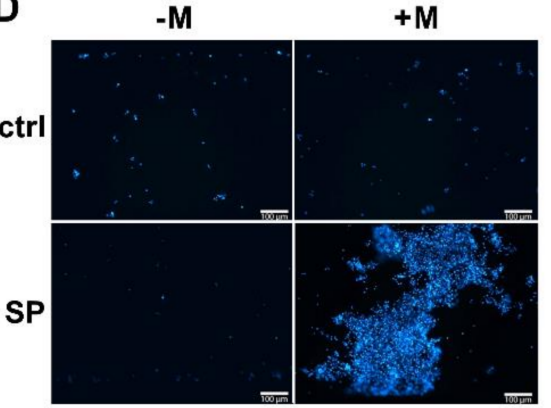

Figure 5. Dynamic magnetic enrichment of T cells. CD3+ T cells were isolated and stimulated for 
$72 \mathrm{~h}$ with a CD3/CD28/CD2 activation mix with $30 \mathrm{IU} / \mathrm{mL}$ IL-2. After three days, the T cells received an additional $30 \mathrm{IU} / \mathrm{mL}$ IL-2 as well as $80 \mu \mathrm{g}$ Fe/mL SPIONs for $24 \mathrm{~h}$. T cells without SPIONs or un-stimulated T cells served as controls. Subsequently, the cells were stained with Hoechst 33342. Dynamic enrichment was performed with a peristaltic pump at a flow velocity of $9.6 \mathrm{~mL} / \mathrm{min}$ for $1 \mathrm{~h}$ in $\mu$-slides I Luer. Magnets were added to locally enrich T cells. For the controls, no magnets were added. The slides were then imaged in fluorescent microscopy to analyze cell count. (A) Depiction of the experimental setup. (B) T cell count after the dynamic enrichment and (C,D) corresponding fluorescent microscopy images of the area where the magnet was placed of non-stimulated (C) and stimulated cells (D). Statistical significances were calculated with an unpaired t test with Welch's correction; ${ }^{* * *} p \leq 0.001$. ctrl: control; SP: SPION; -M: without Magnet; +M: with Magnet; the white scale bar indicates $100 \mu \mathrm{m}$.

\subsection{SPION Loading Does Not Impair Cytokine Release and Differentiation of T Cells after Polyclonal Stimulation}

The ability of loaded $\mathrm{T}$ cells to perform an immune reaction after stimulation is mandatory. We polyclonally stimulated SPION-loaded and non-loaded $\mathrm{T}$ cells with CD3/CD28/CD2 T-cell activator mix overnight. Subsequently, cells were intracellularly stained for cytokine expression such as INF $\gamma, \operatorname{TNF} \alpha$, and IL-2. We found that neither the loading with SPIONs induced cytokine production nor inhibited cytokine expression for both CD4+ and CD8+ cells after polyclonal stimulation (Figure 6).

A

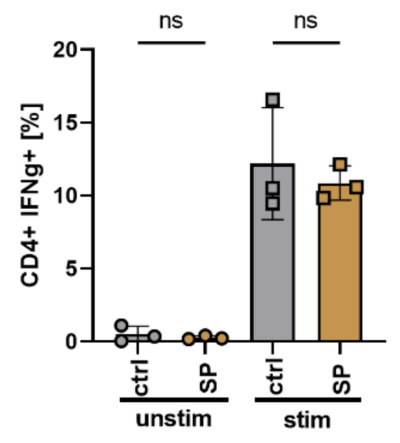

D

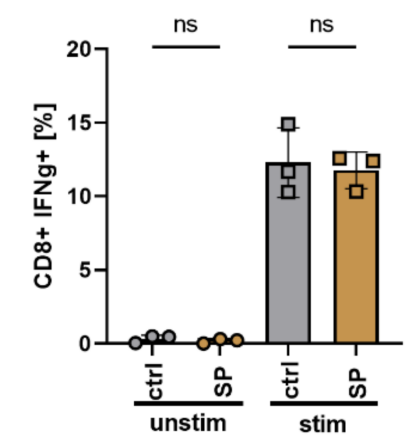

B

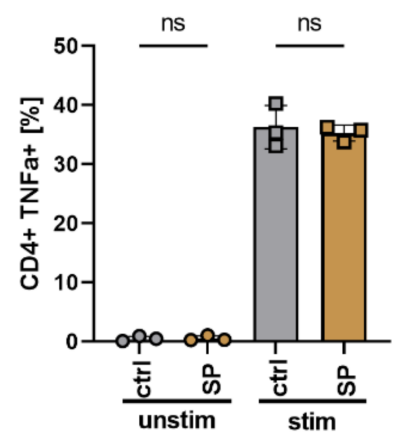

E

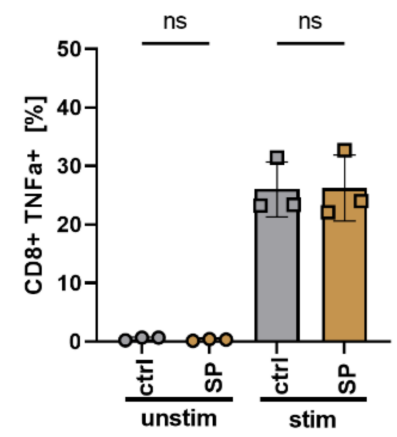

C

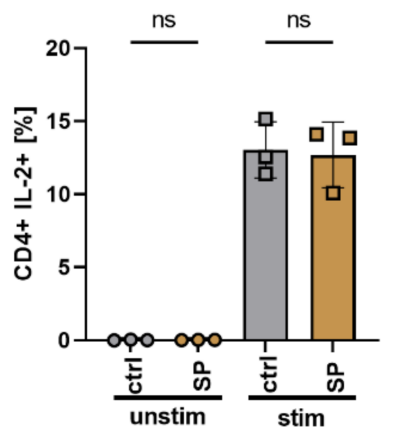

F

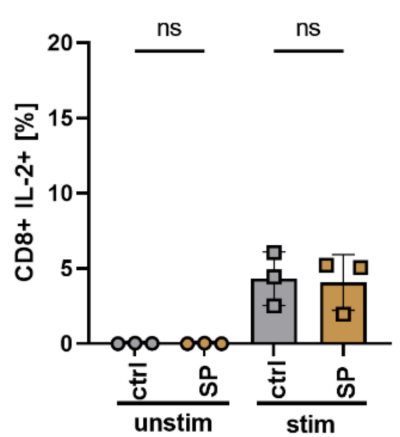

Figure 6. Cytokine expression of T cells after stimulation. Isolated T cells were loaded with $80 \mu \mathrm{g} \mathrm{Fe} / \mathrm{mL}$ SPIONs and were stimulated with a CD3/CD28/CD2 activation mix overnight. $\mathrm{H}_{2} \mathrm{O}$ treated cells and cells without stimulation mix served as controls. The cells were then stained for CD4 and CD8, viability, and cytokine expression. Depicted are the percentages of CD4 (A-C) or CD8 (D-F) T cells expressing TNF $\alpha(\mathbf{A}, \mathbf{D})$, IFN $\gamma(\mathbf{B}, \mathbf{E})$ or IL-2 (C,F). Statistical significances were estimated using an unpaired t test with Welch's correction; (ns): $p \geq 0.05$. ctrl: control; SP: SPIONs; unstim: unstimulated T cells; stim: stimulated T cells. 


\section{Discussion}

The loading of cells with SPIONs enables their control by external magnetic forces. This strategy has been applied for a long time for magnetic associated cell sorting (MACS) in vitro [40] but also represents a great potential for in vivo applications, e.g., for targeted adoptive T cell therapies. For MACS, cells are usually labeled via antibody-conjugated magnetic microbeads, thus, cell labeling enables the isolation of wanted (touched) or unwanted (untouched) cell populations. In contrast to direct targeting of surface markers by antibody-labeled nanoparticles, we use nanoparticles with a citrate shell without any specific targeting moiety. With this, cells can be labeled independently from specific surface structures. Our aim is to make $\mathrm{T}$ cells magnetically attractable to enable site-directed targeting for biomedical applications. For this purpose, $\mathrm{T}$ cells must be loaded with sufficient iron and at the same time, the cellular function must not be impaired. Here we analyzed how experimental conditions influence nanoparticle uptake and cell viability.

Our SPIONs have a negative zeta potential of around $-50 \mathrm{mV}$ at $\mathrm{pH} 7.3$ and a hydrodynamic diameter of $54 \mathrm{~nm}$ in water (Table 1). When exposed to physiological fluids, it is known that the nanoparticle surface is immediately covered by various biomolecules to lower the surface energy [41-43]. Rocker et al. showed that serum proteins such as the abundant albumin, bind nanoparticles [44]. This protein adsorption, referred to as protein corona, essentially determines the "biological identity" of the nanoparticle, which can also explain reduced targeting efficacy of, e.g., antibody-conjugated nanoparticles in vivo [45]. With $10 \%$ FCS in the cell culture medium, our SPIONs remained colloidally stable and roughly $1.4 \mathrm{pg}$ iron was associated with the cells after $3 \mathrm{~h}$ of incubation (Figures 1 and 2). Reduction of the FCS content in cell culture medium to $2 \%$ led to nanoparticle agglomerations and their sedimentation (Figure 1). In parallel, we observed increased cellular levels of iron ( $25 \mathrm{pg} / \mathrm{cell})$, which was probably caused by insufficient removability by washing due to nanoparticle sedimentation. In PBS with $2 \%$ FCS, in fact, no nanoparticle agglomerations were detected, but cellular iron amounts also increased to nearly $3 \mathrm{pg} / \mathrm{cell}$. Thus, in conditions with $2 \%$ FCS only, iron uptake was enhanced but also accompanied by a strong reduction in cell counts (Figure 2). These findings are in line with previous reports by Lesniak et al., who showed much more nanoparticle uptake in the absence of proteins. Analyzing the composition of the protein corona, they found that in the absence of proteins nanoparticles tend to cover themselves with proteins from the plasma membranes, which was exhausting for the cells [46]. This, and the tendency of SPION-loaded cells to aggregate, might have led to a loss of cells in conditions with low protein amounts [47]. Zupke et al. also reported that the presence of human serum proteins reduces the uptake of nanoparticles by CD4+ T cells but preserves cell viability [36].

Besides protein amount, the activation status of the cell was reported to also influence nanoparticle uptake. Others have shown increased incorporation of nanoparticles by activated lymphocytes compared to freshly isolated ones [31,36]. This has been ascribed to the increased macropinocytosis by primary mouse and human $\mathrm{T}$ cells after polyclonal activation to support $\mathrm{T}$ cell growth [48]. Based on these findings, we polyclonally stimulated $\mathrm{T}$ cells to foster nanoparticle uptake. As expected, the T cell count was increased after $72 \mathrm{~h}$, but the stimulated cells did not contain more nanoparticles than the resting ones (Figure 3 ). Contrary to our data, polyclonal activation of the T cells by anti-CD3, anti-CD28, IL-2, and concanavalin A has previously been shown to increase nanoparticle uptake [49]. In this context, the dependence of nanoparticle uptake on the cell cycle has been discussed. Although cells in different phases of the cell cycle internalized nanoparticles at similar rates, cells in the G2/M phase contained more nanoparticles than those in the S or G0/G1 phase. As soon as cells split, cell-associated nanoparticles were divided between daughter cells [39] and, therefore, it was discussed that increased amounts of nanoparticles were rather due to cell size and the number of endosomes than the cell cycle state [50,51].

When we stimulated $\mathrm{T}$ cells after SPION uptake, we found that the release of the cytokines IFN $\gamma, \mathrm{TNF} \alpha$, and IL-2 was not influenced (Figure 6). Thus, these data confirm earlier investigations of our group, that activation after polyclonal stimulation of 
human primary T cells was not impaired by SPION loading [27]. In addition, others have previously shown the biocompatibility of SPIONs [30-32,36].

To analyze the subcellular location of nanoparticles after incubation with $\mathrm{T}$ cells in a cell culture medium containing 10\% FCS, we performed TEM. Although it has been described that the internalization of cationic nanoparticles is more efficient in comparison to neutral or anionic nanoparticles due to the interaction with the positively charged plasma membrane [52,53], we found not only a strong association with the plasma membrane but also remarkable amounts of particles intracellularly enriched in vesicles (Figure 4A). The nanoparticles associated with the plasma membranes were rather bound as thin layers, not in clusters. When comparing with the TEM pictures from others using cationic SPIONs, which achieved up to ten-fold higher iron amounts per cell, their nanoparticles were not taken up but attached to the plasma membrane in multiple layers and clusters, with the risk of detachment from the cells [31]. Since lymphoid cells are non-phagocytic, the uptake of nanoparticles has been frequently described to be low and supporting techniques such as functionalization of the nanoparticles by RGD peptides, coatings derived from viruses, or electroporation of the target cells, were employed for better engulfment [54,55]. The difference in the uptake of nanoparticles dependent on incubation temperature, however, indicated an energy-dependent uptake process with the involvement of endocytic processes for $\mathrm{T}$ cells as well [36].

When analyzing the SSC as a marker for nanoparticle uptake of co-incubated loaded and non-loaded cells, we found that SSC of the single-cell populations did not change; indicating that SPIONs did not spill from loaded cells to initially non-loaded ones. However, when analyzing the iron amount in the loaded T cells, the AES measurements revealed a reduction in iron during the $72 \mathrm{~h}$ observation time, which was not due to cell division, since the analysis was performed with non-proliferating $\mathrm{T}$ cells. Others have previously characterized the export of nanoparticles from $\mathrm{T}$ cells as an energy-dependent active process, taking part within $24 \mathrm{~h}$, which was reduced by lowering of the temperature or use of inhibitors of cell metabolism [36]. Concerning the cellular persistence of SPIONs, both the retention for several days as well as bisection of the MRI signal within the first $24 \mathrm{~h}$ has been reported [56-58]. Whereas SPIONs are superparamagnetic, their degradation products, mainly ferritin and hemosiderin, were anti-ferromagnetic, exhibiting a detectable, but reduced MRI signal [59]. Others previously analyzing the degradation of citratecoated SPIONs in stem cell spheroids found endosomal degradation and upregulation iron homeostasis genes coding for ferritin light chain (iron loading) and ferroportin (iron export) from day 3 onwards [60]. Moreover, after i.v. injection of radioactively labeled SPIONs in mice, after 7 days, 59Fe from the administered nanoparticles appeared in the hemoglobin of newly formed erythrocytes, indicating the intracellular degradation of the nanoparticles. From studies applying SPIONs as contrast agents (Endorem, Resovist), the phenomenon of Fe incorporation into erythrocytes has been well-known [61]. Concerning T cells, it has been found that endosomal acidification was slower and not as robust as in other cells [62]. If SPIONs, in our case, are excreted from the T cells or degraded intracellularly in the lysosomes remains, so far, elusive and must be further investigated. Nonetheless, we detected no spilling to initially non-labeled cells (Figure 4B).

Finally, we analyzed the magnetic retention of the SPION loaded T cells under flow conditions. In magnetic accumulation, the viscosity of the medium, cell radius, and cell velocity are known to play a role [47]. When a permanent magnet generates a magnetic field of about $10-50 \mathrm{~T} / \mathrm{m}$ over a distance of $1 \mathrm{~cm}$, with a $10 \mathrm{pg}$ iron load, a cell experiences a corresponding force of $1 \mathrm{pN}$ to a few $\mathrm{nN}$ [63]. For the investigation of the magnetic accumulation of SPION loaded cells, we used a flow rate of $9.6 \mathrm{~mL} / \mathrm{min}$ for $1 \mathrm{~h}$ at a channel height of $0.4 \mathrm{~mm}$, and a $5 \times 5 \mathrm{~mm}$ sized permanent neodymium magnet with approximately $400 \mathrm{mT}$. With this experimental setup, we were at least able to show in vitro magnetic retention of the SPION-loaded T cells in the wanted area (Figure 5). As with magnetic drug targeting, we are aware that magnetic targeting of cells to the tumor region in vivo is much more ambitious and faces several challenges and pitfalls [64-67]. Exemplarily, tumor 
vascularization may be unfavorable, hindering the delivery of the cells or nanoparticles for drug delivery. However, others previously functionalized lymphocytes with magnetic nanoparticles and showed increased therapeutic success with the adoptive transfer of $\mathrm{T}$ cells and NK cells $[28,35]$. Further, contactless magnetic movement by permanent magnets and dynamically programmable magnetic fields is under intense investigation $[29,68]$. Interestingly, for future translation into clinics, the magnetic field coils inherent to clinical MRI scanners can not only be used for tracking but also for steering magnetic nanoparticles or nanoparticle-loaded cells into the wanted region $[23,24]$, possibly enabling an imagebased therapy in the future.

\section{Conclusions}

Adoptive T cell transfer suffers from poor efficacy in many patients with solid cancers, which is due to low infiltration of the cells into the tumor. The stable and effective loading of $\mathrm{T}$ cells with SPIONs enables their magnetic controllability and accumulation. In summary, we showed here that we can load primary human CD3+ T cells with SPIONs. We found that loading efficacy and cell viability was dependent on the amount of serum present in the cell culture medium. The activation of the cells, however, did not affect nanoparticle uptake. With our loading strategy, we achieved $1.4 \mathrm{pg}$ Fe/iron per cell, which was enough to accumulate the cells in a dynamic flow system. Furthermore, we found that SPIONs were located intracellularly in vesicles or tightly attached to the plasma membrane, without spillover to non-loaded cells. With stable and sufficient iron loading, T cells become not only magnetically controllable but can enable tracking of injected cells using MRI.

Supplementary Materials: The following are available online at https: / www.mdpi.com/article / 10.3390/cancers13164143/s1: Supplementary Figure S1: Efficacy of T cell isolation using IBA CD3 Fab-TACS gravity columns.

Author Contributions: Conceptualization: C.J. and C.A.; methodology, M.M., L.F. and S.L.; software, P.B., F.P. and L.F.; validation, E.S. and J.B.; formal analysis, P.B. and F.P.; investigation, P.B., F.P., R.S., B.F., J.B. and E.S.; resources, C.A. and D.D; data curation, P.B., F.P. and C.J.; writing-original draft preparation, P.B., and F.P.; writing - review and editing, C.A., C.J. and S.L.; visualization, P.B., F.P. and L.F.; supervision, C.J. and C.A.; project administration, C.J.; funding acquisition, C.A., C.J. and D.D. All authors have read and agreed to the published version of the manuscript.

Funding: This research was funded by the Else Kröner Fresenius Stiftung, Bad Homburg v.d.H., Germany (2018_A88) to C.J. and Deutsche Forschungsgemeinschaft (DFG)-SFB TRR 305-B05, DU54851 to D.D. as well as intramurally by the Emerging Fields Initiative EFI-BIG-Thera and the StaedlerStiftung to D.D. and C.A.

Institutional Review Board Statement: The study was conducted according to the guidelines of the Declaration of Helsinki, and approved by the Ethics Committee of the Friedrich-Alexander Universität Erlangen-Nürnberg (protocol code 257_14B; approved on 18 September 2014 and pro-longed on 2 February 2018).

Informed Consent Statement: Informed consent was obtained from all subjects involved in the study.

Data Availability Statement: No new data were created or analyzed in this study. Data sharing is not applicable to this article.

Acknowledgments: The present work was performed in fulfilment of the requirements for ob-taining the degree "Dr. med." (Philipp Boosz) at the Friedrich-Alexander-Universität (FAU), Er-langenNürnberg, Germany. We acknowledge Andrea Kerpes for her excellent technical support in the cell culture and Anita Hecht and Andrea Hilpert for operating the TEM.

Conflicts of Interest: The authors declare no conflict of interest. 


\section{References}

1. Mattiuzzi, C.; Lippi, G. Current Cancer Epidemiology. J. Epidemiol. Glob. Health 2019, 9, 217-222. [CrossRef]

2. Galon, J.; Costes, A.; Sanchez-Cabo, F.; Kirilovsky, A.; Mlecnik, B.; Lagorce-Pages, C.; Tosolini, M.; Camus, M.; Berger, A.; Wind, P.; et al. Type, density, and location of immune cells within human colorectal tumors predict clinical outcome. Science 2006, 313, 1960-1964. [CrossRef] [PubMed]

3. Jass, J.R. Lymphocytic infiltration and survival in rectal cancer. J. Clin. Pathol. 1986, 39, 585-589. [CrossRef] [PubMed]

4. Kim, S.T.; Jeong, H.; Woo, O.H.; Seo, J.H.; Kim, A.; Lee, E.S.; Shin, S.W.; Kim, Y.H.; Kim, J.S.; Park, K.H. Tumor-infiltrating lymphocytes, tumor characteristics, and recurrence in patients with early breast cancer. Am. J. Clin. Oncol. 2013, 36, 224-231. [CrossRef] [PubMed]

5. Kmiecik, J.; Poli, A.; Brons, N.H.; Waha, A.; Eide, G.E.; Enger, P.O.; Zimmer, J.; Chekenya, M. Elevated CD3+ and CD8+ tumorinfiltrating immune cells correlate with prolonged survival in glioblastoma patients despite integrated immunosuppressive mechanisms in the tumor microenvironment and at the systemic level. J. Neuroimmunol. 2013, 264, 71-83. [CrossRef]

6. Dudley, M.E.; Rosenberg, S.A. Adoptive-cell-transfer therapy for the treatment of patients with cancer. Nat. Rev. Cancer 2003, 3, 666-675. [CrossRef]

7. Bernhard, H.; Neudorfer, J.; Gebhard, K.; Conrad, H.; Hermann, C.; Nahrig, J.; Fend, F.; Weber, W.; Busch, D.H.; Peschel, C. Adoptive transfer of autologous, HER2-specific, cytotoxic T lymphocytes for the treatment of HER2-overexpressing breast cancer. Cancer Immunol. Immunother. 2008, 57, 271-280. [CrossRef]

8. Pockaj, B.A.; Sherry, R.M.; Wei, J.P.; Yannelli, J.R.; Carter, C.S.; Leitman, S.F.; Carasquillo, J.A.; Steinberg, S.M.; Rosenberg, S.A.; Yang, J.C. Localization of 111indium-labeled tumor infiltrating lymphocytes to tumor in patients receiving adoptive immunotherapy. Augmentation with cyclophosphamide and correlation with response. Cancer 1994, 73, 1731-1737. [CrossRef]

9. Sanz-Ortega, L.; Rojas, J.M.; Barber, D.F. Improving Tumor Retention of Effector Cells in Adoptive Cell Transfer Therapies by Magnetic Targeting. Pharmaceutics 2020, 12, 812. [CrossRef]

10. Bargou, R.; Leo, E.; Zugmaier, G.; Klinger, M.; Goebeler, M.; Knop, S.; Noppeney, R.; Viardot, A.; Hess, G.; Schuler, M.; et al. Tumor regression in cancer patients by very low doses of a T cell-engaging antibody. Science 2008, 321, 974-977. [CrossRef]

11. Schlegel, P.; Lang, P.; Zugmaier, G.; Ebinger, M.; Kreyenberg, H.; Witte, K.E.; Feucht, J.; Pfeiffer, M.; Teltschik, H.M.; Kyzirakos, C.; et al. Pediatric posttransplant relapsed/refractory B-precursor acute lymphoblastic leukemia shows durable remission by therapy with the T-cell engaging bispecific antibody blinatumomab. Haematologica 2014, 99, 1212-1219. [CrossRef] [PubMed]

12. Topp, M.S.; Kufer, P.; Gokbuget, N.; Goebeler, M.; Klinger, M.; Neumann, S.; Horst, H.A.; Raff, T.; Viardot, A.; Schmid, M.; et al. Targeted therapy with the T-cell-engaging antibody blinatumomab of chemotherapy-refractory minimal residual disease in B-lineage acute lymphoblastic leukemia patients results in high response rate and prolonged leukemia-free survival. J. Clin. Oncol. 2011, 29, 2493-2498. [CrossRef] [PubMed]

13. Klinger, M.; Brandl, C.; Zugmaier, G.; Hijazi, Y.; Bargou, R.C.; Topp, M.S.; Gökbuget, N.; Neumann, S.; Goebeler, M.; Viardot, A.; et al. Immunopharmacologic response of patients with B-lineage acute lymphoblastic leukemia to continuous infusion of $\mathrm{T}$ cell-engaging CD19/CD3-bispecific BiTE antibody blinatumomab. Blood 2012, 119, 6226-6233. [CrossRef] [PubMed]

14. Tietze, R.; Lyer, S.; Durr, S.; Struffert, T.; Engelhorn, T.; Schwarz, M.; Eckert, E.; Goen, T.; Vasylyev, S.; Peukert, W.; et al. Efficient drug-delivery using magnetic nanoparticles_biodistribution and therapeutic effects in tumour bearing rabbits. Nanomedicine 2013, 9, 961-971. [CrossRef]

15. Liang, P.C.; Chen, Y.C.; Chiang, C.F.; Mo, L.R.; Wei, S.Y.; Hsieh, W.Y.; Lin, W.L. Doxorubicin-modified magnetic nanoparticles as a drug delivery system for magnetic resonance imaging-monitoring magnet-enhancing tumor chemotherapy. Int. J. Nanomed. 2016, 11, 2021-2037.

16. Pan, C.; Liu, Y.; Zhou, M.; Wang, W.; Shi, M.; Xing, M.; Liao, W. Theranostic pH-sensitive nanoparticles for highly efficient targeted delivery of doxorubicin for breast tumor treatment. Int. J. Nanomed. 2018, 13, 1119-1137. [CrossRef]

17. Jin, H.; Qian, Y.; Dai, Y.; Qiao, S.; Huang, C.; Lu, L.; Luo, Q.; Chen, J.; Zhang, Z. Magnetic Enrichment of Dendritic Cell Vaccine in Lymph Node with Fluorescent-Magnetic Nanoparticles Enhanced Cancer Immunotherapy. Theranostics 2016, 6, 2000-2014. [CrossRef]

18. Polyak, B.; Fishbein, I.; Chorny, M.; Alferiev, I.; Williams, D.; Yellen, B.; Friedman, G.; Levy, R.J. High field gradient targeting of magnetic nanoparticle-loaded endothelial cells to the surfaces of steel stents. Proc. Natl. Acad. Sci. USA 2008, 105, 698-703. [CrossRef]

19. Tukmachev, D.; Lunov, O.; Zablotskii, V.; Dejneka, A.; Babic, M.; Sykova, E.; Kubinova, S. An effective strategy of magnetic stem cell delivery for spinal cord injury therapy. Nanoscale 2015, 7, 3954-3958. [CrossRef]

20. Baeten, K.; Adriaensens, P.; Hendriks, J.; Theunissen, E.; Gelan, J.; Hellings, N.; Stinissen, P. Tracking of myelin-reactive T cells in experimental autoimmune encephalomyelitis (EAE) animals using small particles of iron oxide and MRI. NMR Biomed. 2010, 23, 601-609. [CrossRef]

21. Liu, L.; Ye, Q.; Wu, Y.; Hsieh, W.Y.; Chen, C.L.; Shen, H.H.; Wang, S.J.; Zhang, H.; Hitchens, T.K.; Ho, C. Tracking T-cells in vivo with a new nano-sized MRI contrast agent. Nanomedicine 2012, 8, 1345-1354. [CrossRef]

22. Beer, A.J.; Holzapfel, K.; Neudorfer, J.; Piontek, G.; Settles, M.; Kronig, H.; Peschel, C.; Schlegel, J.; Rummeny, E.J.; Bernhard, H. Visualization of antigen-specific human cytotoxic T lymphocytes labeled with superparamagnetic iron-oxide particles. Eur. Radiol. 2008, 18, 1087-1095. [CrossRef] [PubMed] 
23. Muthana, M.; Kennerley, A.J.; Hughes, R.; Fagnano, E.; Richardson, J.; Paul, M.; Murdoch, C.; Wright, F.; Payne, C.; Lythgoe, M.F.; et al. Directing cell therapy to anatomic target sites in vivo with magnetic resonance targeting. Nat. Commun. 2015, 6, 8009. [CrossRef] [PubMed]

24. Riegler, J.; Wells, J.A.; Kyrtatos, P.G.; Price, A.N.; Pankhurst, Q.A.; Lythgoe, M.F. Targeted magnetic delivery and tracking of cells using a magnetic resonance imaging system. Biomaterials 2010, 31, 5366-5371. [CrossRef] [PubMed]

25. Mühlberger, M.; Janko, C.; Unterweger, H.; Friedrich, R.P.; Friedrich, B.; Band, J.; Cebulla, N.; Alexiou, C.; Dudziak, D.; Lee, G.; et al. Functionalization of T Lymphocytes with Citrate-Coated Superpara-magnetic Iron Oxide Nanoparticles for Magnetically Controlled Immune Therapy. Int. J. Nanomed. 2019, 14, 8421-8432. [CrossRef] [PubMed]

26. Mühlberger, M.; Janko, C.; Unterweger, H.; Schreiber, E.; Band, J.; Lehmann, C.; Dudziak, D.; Lee, G.; Alexiou, C.; Tietze, R. Functionalization of $\mathrm{T}$ lymphocytes for magnetically controlled immune therapy: Selection of suitable superparamagnetic iron oxide nanoparticles. J. Magn. Magn. Mater. 2019, 473, 61-67. [CrossRef]

27. Mühlberger, M.; Unterweger, H.; Band, J.; Lehmann, C.; Heger, L.; Dudziak, D.; Alexiou, C.; Lee, G.; Janko, C. Loading of Primary Human T Lymphocytes with Citrate-Coated Superparamagnetic Iron Oxide Nanoparticles Does Not Impair Their Activation after Polyclonal Stimulation. Cells 2020, 9, 342. [CrossRef]

28. Nie, W.; Wei, W.; Zuo, L.; Lv, C.; Zhang, F.; Lu, G.H.; Li, F.; Wu, G.; Huang, L.L.; Xi, X.; et al. Magnetic Nanoclusters Armed with Responsive PD-1 Antibody Synergistically Improved Adoptive T-Cell Therapy for Solid Tumors. ACS Nano 2019, 13, 1469-1478. [CrossRef]

29. Pai, A.; Cao, P.; White, E.E.; Hong, B.; Pailevanian, T.; Wang, M.; Badie, B.; Hajimiri, A.; Berlin, J.M. Dynamically Programmable Magnetic Fields for Controlled Movement of Cells Loaded with Iron Oxide Nanoparticles. ACS Appl. Bio Mater. 2020, 3, $4139-4147$. [CrossRef]

30. Sanz-Ortega, L.; Portilla, Y.; Pérez-Yagüe, S.; Barber, D.F. Magnetic targeting of adoptively transferred tumour-specific nanoparticle-loaded CD8(+) T cells does not improve their tumour infiltration in a mouse model of cancer but promotes the retention of these cells in tumour-draining lymph nodes. J. Nanobiotechnol. 2019, 17, 87. [CrossRef]

31. Sanz-Ortega, L.; Rojas, J.M.; Marcos, A.; Portilla, Y.; Stein, J.V.; Barber, D.F. T cells loaded with magnetic nanoparticles are retained in peripheral lymph nodes by the application of a magnetic field. J. Nanobiotechnol. 2019, 17, 14. [CrossRef]

32. Sanz-Ortega, L.; Rojas, J.M.; Portilla, Y.; Pérez-Yagüe, S.; Barber, D.F. Magnetic Nanoparticles Attached to the NK Cell Surface for Tumor Targeting in Adoptive Transfer Therapies Does Not Affect Cellular Effector Functions. Front. Immunol. 2019, 10, 2073. [CrossRef] [PubMed]

33. Foroozandeh, P.; Aziz, A.A. Insight into Cellular Uptake and Intracellular Trafficking of Nanoparticles. Nanoscale Res. Lett. 2018, 13, 339. [CrossRef] [PubMed]

34. Waiczies, S.; Niendorf, T.; Lombardi, G. Labeling of cell therapies: How can we get it right? Oncoimmunology 2017, 6, e1345403. [CrossRef] [PubMed]

35. Sim, T.; Choi, B.; Kwon, S.W.; Kim, K.S.; Choi, H.; Ross, A.; Kim, D.H. Magneto-Activation and Magnetic Resonance Imaging of Natural Killer Cells Labeled with Magnetic Nanocomplexes for the Treatment of Solid Tumors. ACS Nano 2021. [CrossRef] [PubMed]

36. Zupke, O.; Distler, E.; Jürchott, A.; Paiphansiri, U.; Dass, M.; Thomas, S.; Hartwig, U.F.; Theobald, M.; Landfester, K.; Mailänder, V.; et al. Nanoparticles and antigen-specific T-cell therapeutics: A comprehensive study on uptake and release. Nanomedicine 2015, 10, 1063-1076. [CrossRef] [PubMed]

37. Elbialy, N.S.; Fathy, M.M.; Khalil, W.M. Doxorubicin loaded magnetic gold nanoparticles for in vivo targeted drug delivery. Int. J. Pharm. 2015, 490, 190-199. [CrossRef] [PubMed]

38. Friedrich, R.P.; Janko, C.; Poettler, M.; Tripal, P.; Zaloga, J.; Cicha, I.; Dürr, S.; Nowak, J.; Odenbach, S.; Slabu, I.; et al. Flow cytometry for intracellular SPI-ON quantification: Specificity and sensitivity in comparison with spectroscopic methods. Int. J. Nanomed. 2015, 10, 4185-4201. [CrossRef]

39. Kim, J.A.; Aberg, C.; Salvati, A.; Dawson, K.A. Role of cell cycle on the cellular uptake and dilution of nanoparticles in a cell population. Nat. Nanotechnol. 2011, 7, 62-68. [CrossRef]

40. Miltenyi, S.; Muller, W.; Weichel, W.; Radbruch, A. High gradient magnetic cell separation with MACS. Cytometry 1990, 11, 231-238. [CrossRef]

41. Lynch, I.; Salvati, A.; Dawson, K.A. Proteinnanoparticle interactions: What does the cell see? Nat. Nanotechnol. 2009, 4, 546-547. [CrossRef]

42. Mahmoudi, M.; Lynch, I.; Ejtehadi, M.R.; Monopoli, M.P.; Bombelli, F.B.; Laurent, S. Protein-nanoparticle interactions: Opportunities and challenges. Chem. Rev. 2011, 111, 5610-5637. [CrossRef]

43. Nel, A.E.; Mädler, L.; Velegol, D.; Xia, T.; Hoek, E.M.V.; Somasundaran, P.; Klaessig, F.; Castranova, V.; Thompson, M. Understanding biophysicochemical interactions at the nano-bio interface. Nat. Mater. 2009, 8, 543-557. [CrossRef] [PubMed]

44. Rocker, C.; Potzl, M.; Zhang, F.; Parak, W.J.; Nienhaus, G.U. A quantitative fluorescence study of protein monolayer formation on colloidal nanoparticles. Nat. Nanotechnol. 2009, 4, 577-580. [CrossRef] [PubMed]

45. Hadjidemetriou, M.; Al-Ahmady, Z.; Mazza, M.; Collins, R.F.; Dawson, K.; Kostarelos, K. In Vivo Biomolecule Corona around Blood-Circulating, Clinically Used and Antibody-Targeted Lipid Bilayer Nanoscale Vesicles. ACS Nano 2015, 9, 8142-8156. [CrossRef] [PubMed] 
46. Lesniak, A.; Fenaroli, F.; Monopoli, M.P.; Aberg, C.; Dawson, K.A.; Salvati, A. Effects of the presence or absence of a protein corona on silica nanoparticle uptake and impact on cells. ACS Nano 2012, 6, 5845-5857. [CrossRef] [PubMed]

47. Kolosnjaj-Tabi, J.; Wilhelm, C.; Clement, O.; Gazeau, F. Cell labeling with magnetic nanoparticles: Opportunity for magnetic cell imaging and cell manipulation. J. Nanobiotechnol. 2013, 11 (Suppl. 1), S7. [CrossRef]

48. Charpentier, J.C.; Chen, D.; Lapinski, P.E.; Turner, J.; Grigorova, I.; Swanson, J.A.; King, P.D. Macropinocytosis drives T cell growth by sustaining the activation of mTORC1. Nat. Commun. 2020, 11, 180. [CrossRef] [PubMed]

49. Dodd, C.H.; Hsu, H.C.; Chu, W.J.; Yang, P.; Zhang, H.G.; Mountz, J.D., Jr.; Zinn, K.; Forder, J.; Josephson, L.; Weissleder, R.; et al. Normal T-cell response and in vivo magnetic resonance imaging of T cells loaded with HIV transactivator-peptide-derived superparamagnetic nanoparticles. J. Immunol. Methods 2001, 256, 89-105. [CrossRef]

50. Panet, E.; Mashriki, T.; Lahmi, R.; Jacob, A.; Ozer, E.; Vecsler, M.; Lazar, I.; Tzur, A. The interface of nanoparticles with proliferating mammalian cells. Nat. Nanotechnol. 2017, 12, 598-600. [CrossRef]

51. Rees, P.; Wills, J.W.; Brown, M.R.; Barnes, C.M.; Summers, H.D. The origin of heterogeneous nanoparticle uptake by cells. Nat. Commun. 2019, 10, 2341. [CrossRef] [PubMed]

52. Frohlich, E. The role of surface charge in cellular uptake and cytotoxicity of medical nanoparticles. Int. J. Nanomed. 2012, 7 , 5577-5591. [CrossRef]

53. Jambhrunkar, S.; Qu, Z.; Popat, A.; Yang, J.; Noonan, O.; Acauan, L.; Ahmad Nor, Y.; Yu, C.; Karmakar, S. Effect of surface functionality of silica nanoparticles on cellular uptake and cytotoxicity. Mol. Pharm. 2014, 11, 3642-3655. [CrossRef] [PubMed]

54. Garden, O.A.; Reynolds, P.R.; Yates, J.; Larkman, D.J.; Marelli-Berg, F.M.; Haskard, D.O.; Edwards, A.D.; George, A.J. A rapid method for labelling CD4+ T cells with ultrasmall paramagnetic iron oxide nanoparticles for magnetic resonance imaging that preserves proliferative, regulatory and migratory behaviour in vitro. J. Immunol. Methods 2006, 314, 123-133. [CrossRef] [PubMed]

55. Lankoff, A.; Arabski, M.; Wegierek-Ciuk, A.; Kruszewski, M.; Lisowska, H.; Banasik-Nowak, A.; Rozga-Wijas, K.; Wojewodzka, M.; Slomkowski, S. Effect of surface modification of silica nanoparticles on toxicity and cellular uptake by human peripheral blood lymphocytes in vitro. Nanotoxicology 2013, 7, 235-250. [CrossRef] [PubMed]

56. Kaufman, C.L.; Williams, M.; Ryle, L.M.; Smith, T.L.; Tanner, M.; Ho, C. Superparamagnetic iron oxide particles transactivator protein-fluorescein isothiocyanate particle labeling for in vivo magnetic resonance imaging detection of cell migration: Uptake and durability. Transplantation 2003, 76, 1043-1046. [CrossRef]

57. Kircher, M.F.; Allport, J.R.; Graves, E.E.; Love, V.; Josephson, L.; Lichtman, A.H.; Weissleder, R. In vivo high resolution threedimensional imaging of antigen-specific cytotoxic T-lymphocyte trafficking to tumors. Cancer Res. 2003, 63, $6838-6846$.

58. Smirnov, P.; Lavergne, E.; Gazeau, F.; Lewin, M.; Boissonnas, A.; Doan, B.-T.; Gillet, B.; Combadière, C.; Combadière, B.; Clément, O. In vivo cellular imaging of lymphocyte trafficking by MRI: A tumor model approach to cell-based anticancer therapy. Magn. Reson. Med. 2006, 56, 498-508. [CrossRef]

59. Briley-Saebo, K.; Bjornerud, A.; Grant, D.; Ahlstrom, H.; Berg, T.; Kindberg, G.M. Hepatic cellular distribution and degradation of iron oxide nanoparticles following single intravenous injection in rats: Implications for magnetic resonance imaging. Cell Tissue Res. 2004, 316, 315-323. [CrossRef]

60. Mazuel, F.; Espinosa, A.; Luciani, N.; Reffay, M.; Le Borgne, R.; Motte, L.; Desboeufs, K.; Michel, A.; Pellegrino, T.; Lalatonne, Y.; et al. Massive Intracellular Biodegradation of Iron Oxide Nanoparticles Evidenced Magnetically at Single-Endosome and Tissue Levels. ACS Nano 2016, 10, 7627-7638. [CrossRef]

61. Feliu, N.; Docter, D.; Heine, M.; Del Pino, P.; Ashraf, S.; Kolosnjaj-Tabi, J.; Macchiarini, P.; Nielsen, P.; Alloyeau, D.; Gazeau, F.; et al. In vivo degeneration and the fate of inorganic nanoparticles. Chem. Soc. Rev. 2016, 45, 2440-2457. [CrossRef] [PubMed]

62. Olden, B.R.; Cheng, E.; Cheng, Y.; Pun, S.H. Identifying key barriers in cationic polymer gene delivery to human T cells. Biomater. Sci. 2019, 7, 789-797. [CrossRef] [PubMed]

63. Wilhelm, C.; Riviere, C.; Biais, N. Magnetic control of Dictyostelium aggregation. Phys. Rev. E Stat. Nonlin. Soft Matter Phys. 2007, 75 Pt 1, 041906. [CrossRef]

64. Park, K. Facing the truth about nanotechnology in drug delivery. ACS Nano 2013, 7, 7442-7447. [CrossRef] [PubMed]

65. Shi, J.; Kantoff, P.W.; Wooster, R.; Farokhzad, O.C. Cancer nanomedicine: Progress, challenges and opportunities. Nat. Rev. Cancer 2017, 17, 20-37. [CrossRef] [PubMed]

66. Torrice, M. Does Nanomedicine Have a Delivery Problem? ACS Cent. Sci. 2016, 2, 434-437. [CrossRef] [PubMed]

67. Wilhelm, C.; Gazeau, F. Universal cell labelling with anionic magnetic nanoparticles. Biomaterials 2008, 29 , 3161-3174. [CrossRef] [PubMed]

68. Blumler, P.; Friedrich, R.P.; Pereira, J.; Baun, O.; Alexiou, C.; Mailander, V. Contactless Nanoparticle-Based Guiding of Cells by Controllable Magnetic Fields. Nanotechnol. Sci. Appl. 2021, 14, 91-100. [CrossRef] 